\title{
ŠTO JOŠ ONE ŽELE? RAZVOJ NOVE SKALE ZA MJERENJE SUVREMENIH OBLIKA SEKSIZMA
}

\author{
Bruno Šimac i Ksenija Klasnić
}

\author{
Odsjek za sociologiju \\ Filozofski fakultet, Sveučilište u Zagrebu \\ Ivana Lučića 3, 10000 Zagreb \\ e-mail: bsimac@ffzg.hr
}

\begin{abstract}
Sažetak
Predrasude prema ženama, u obliku seksizma, tradicionalno su bile okarakterizirane zagovaranjem strogih rodnih uloga. No, uslijed kulturnih i političkih promjena posljednjih desetljeća, otvorena diskriminacija prema ženama postaje društveno neprihvatljiva, a seksizam preuzima nove, suvremene oblike koji često prolaze nezapaženo, tajno i skriveno. Cilj je ovoga rada konstruirati i evaluirati novu Skalu suvremenog seksizma koja će objediniti nekoliko do sad konceptualno razdvojenih oblika suvremenog seksizma, kao i neke sadržaje koji do sad nisu bili uključeni u postojeće skale suvremenih oblika seksizma. Oslanjajući se na tri tipa konceptualno-operacionalnih razrada suvremenog seksizma - moderni seksizam Swim i suradnica (1995), neoseksizam Tougas i suradnika (1995) te ambivalentni seksizam Glicka i Fiske (1996), konceptualno i operacionalno su razradeni suvremeni seksistički stavovi u četiri temeljne sadržajne domene: 1 . nijekanje postojanja daljnje diskriminacije žena; 2. antagonizam spram zahtjeva žena; 3. ogorčenje zbog posebnih pogodnosti koje žene dobivaju samo zbog toga što su žene; te 4. zamjeranje ženama zbog "preosjetljivosti" na seksizam i seksualno uznemiravanje. Istraživanje je provedeno metodom ankete na prigodnom uzorku od 402 studentice i studenta različitih sastavnica Sveučilišta u Zagrebu. Konačnu inačicu Skale suvremenog seksizma (SSS) čini 27 čestica, a skala predstavlja jednodimenzionalan mjerni konstrukt. Na temelju provedenih analiza autori zaključuju da je SSS instrument visoke pouzdanosti te zadovoljavajuće sadržajne, kriterijske i konstruktne valjanosti i sugeriraju neke daljnje smjernice za njegovo korištenje u anketnim istraživanjima.
\end{abstract}

Ključne riječi: diskriminacija žena, rodna neravnopravnost, Skala suvremenog seksizma (SSS), suvremeni seksizam, tradicionalni seksizam, stavovi prema feminističkom pokretu

\section{UVOD ${ }^{1}$}

Različiti tipovi društvenih nejednakosti obilježavaju suvremeni svijet. Dok su se društvene nejednakosti do 1960-ih i 1970-ih godina pretežno istraživale u kategorijama klasne stratifikacije i religijskih razlika, od 1980-ih do izražaja sve više dolaze novi oblici

1 Rad je nastao na temelju istraživanja provedenog za potrebe diplomskog rada Brune Šimca naslovljenom „Mjerenje suvremenih oblika seksizma: razvoj nove skale“, koji je obranjen 2017. godine pod mentorstvom doc. dr. sc. Ksenije Klasnić na Odsjeku za sociologiju Filozofskog fakulteta Sveučilišta u Zagrebu. 
nejednakosti i neravnopravnosti, među kojima se posebno ističe rodna neravnopravnost. Temeljne preobrazbe rodnih odnosa u suvremenom zapadnom svijetu utječu na sve ostale oblike društvenih odnosa. Promjene pokrenute masovnim obrazovanjem žena i njihovog plaćenog zapošljavanja, kao i novim oblicima političkog zastupanja interesa žena, dovele su i do promjena u sustavu rodnih odnosa. Dok su žene prije uglavnom bile ograničene na obiteljsku sferu, danas su prisutne i u javnoj sferi, ali i dalje često u neravnopravnom položaju (Walby, 2005). Taj se neravnopravan položaj očituje u rodnoj diskriminaciji koja podrazumijeva nejednaku raspodjelu moći, resursa i privilegija, u pravilu u korist muškaraca, odnosno, na štetu žena (Galić, 2012).

Poseban oblik odobravanja diskriminatornih ili predrasudnih uvjerenja na temelju spola naziva se seksizam (Campbell i sur., 1997), a može se definirati i kao: „društveni i kulturni fenomen diskriminiranja ili segregiranja neke rodne grupe na temelju pripadnosti spolu i / ili rodu" (Galić, 2012:156). Predrasude i diskriminacija spram žena u obliku seksizma tradicionalno su bile okarakterizirane zagovaranjem strogih rodnih uloga (prema kojima su žene submisivne skrbnice i njegovateljice, a muškarci hranitelji obitelji), vjerovanjem u inkompetenciju žena, te različitim tretmanom muškaraca i žena. No, uslijed kulturnih i političkih promjena posljednjih desetljeća, otvorena diskriminacija žena postaje ilegalna (npr. Članak 3 Ustava Republike Hrvatske ističe ravnopravnost spolova kao jednu od najviših vrednota ustavnog poretka RH; NN, 56/90, 135/97, 08/98, 113/00, 124/00, 28/01, 41/01, 55/01, 76/10, 85/10, 05/14) i društveno neprihvatljiva, a seksizam preuzima novi, prikriveni oblik (Huber, 2016). Stoga, premda su normativne i zakonske promjene $\mathrm{u}$ industrijski razvijenim zemljama pridonijele mijenjanju obrazaca seksizma, one su više uvjetovale njegovo prikrivanje negoli eliminiranje (Masser i Abrams, 1999). Prema jednoj mogućoj klasifikaciji, seksizam se u suvremenom svijetu pojavljuje u dva oblika: otvorenom i prikrivenom. U otvorenom se obliku pojavljuje u nizu društvenih aktivnosti u vidu otvorenih i očitih zabrana za pripadnike ili pripadnice određenog spola, a prikrivenog oblika mnoge žene i muškarci nisu niti svjesni jer najčešće prolazi nezapaženo, tajno i skriveno (Barada i Jelavić, 2004).

Suvremeni oblici seksizma u hrvatskoj su sociologiji mjereni tek u nekoliko navrata (Galić i Nikodem, 2006; Čulig i sur., 2007; Galić, 2008 i 2012; Galić i Klasnić, 2012; Klasnić i Štulhofer, 2018), dok je međunarodna znanstvena scena bogata brojnim teorijskim i empirijskim radovima (Swim i sur., 1995; Glick i Fiske, 1996; Campbell i sur., 1997; Swim i Cohen, 1997; Morrison i sur., 1999; Masser i Abrams, 1999; Huber, 2016; Stoll i sur., 2017 itd.). U većini domaćih i međunarodnih radova nije postignut konsenzus o razlikovanju koncepata modernog seksizma i neoseksizma. Dok se u stranoj literaturi ovi koncepti predstavljaju kao slični, ali ipak razdijeljeni konstrukti (Masser i Abrams, 1999), u domaćoj se literaturi većinom izjednačavaju (Galić, 2012).

\section{SUVREMENI OBLICI SEKSIZMA}

Političke i sociokulturne promjene u drugoj polovici dvadesetog stoljeća, koje su ukazale na nužnost postizanja rodne ravnopravnosti, dovode do pojave novih oblika seksizma zbog 
toga što otvoreno iskazivanje predrasudnih mišljenja prema ženama postaje društveno nepoželjno, a u nekim slučajevima i ilegalno (Tougas i sur., 1995). Tako Benokraitis i Feagin (1986 i 1995 prema Swim i Cohen, 1997) „otvorenom“ ili „očitom“ seksizmu pridodaju i dva suvremena oblika - „prikriveni“ i ,suptilni“. Otvoreni, očiti ili tradicionalni seksizam predstavljen je kao nejednako i štetno postupanje prema ženama koje je jednostavno uočiti. S druge pak strane, prikriveni seksizam uključuje nejednako i štetno postupanje prema ženama na skriveni i tajan način, a suptilni je seksizam okarakteriziran otvorenim nejednakim i štetnim postupanjem prema ženama koje prolazi nezapaženo jer se smatra uobičajenim ili normalnim ponašanjem (Benokraitis i Feagin, 1986 i 1995, prema Swim i Cohen, 1997). Na temelju ovakve i sličnih konceptualizacija, sredinom posljednjeg desetljeća dvadesetog stoljeća provode se brojna istraživanja različitih shvaćanja suvremenog seksizma, odnosno suvremenih predrasuda koje su najčešće izražene na suptilan način. Za potrebe ovog istraživanja usredotočili smo se na tri tipa konceptualizacije i operacionalizacije suvremenih oblika seksizma: 1. staromodni i moderni seksizam (Swim i sur., 1995); 2. neoseksizam (Tougas i sur., 1995); te 3. ambivalentni seksizam (Glick i Fiske, 1996).

\subsection{Staromodni i moderni seksizam}

Swim i suradnice (1995), proučavajući istraživanja rasizma (McConahay, 1986 prema Swim i sur., 1995), uočavaju brojne sličnosti između diskriminacije Afro-Amerikanaca i žena. Stoga razvijaju koncepte staromodnog seksizma i modernog seksizma. Staromodni seksizam (engl. old-fashioned sexism) odražava tradicionalna vjerovanja koja se odnose na rodnu diferencijaciju u smislu muških i ženskih rodnih uloga, različitog tretmana muškaraca i žena te ženske inkompetencije (Conn i sur., 1999). S druge strane, moderni seksizam (engl. modern sexism) karakterizira „nijekanje postojanja daljnje diskriminacije temeljene na rodu i osjećaja da žene traže prevelika prava što u konačnici rezultira u nesklonosti i otporu spram ženskih zahtjeva" (Campbell i sur., 1997:90). Sukladno konceptualnoj sličnosti modernog seksizma s modernim rasizmom, ključne odrednice modernog seksizma su: 1. nijekanje postojanja daljnje diskriminacije žena; 2. antagonizam spram zahtjeva žena; te 3 . ogorčenje zbog posebnih pogodnosti koje žene dobivaju samo zbog toga što su žene (Swim i sur., 1997).

\subsection{Neoseksizam}

Istovremeno, Tougas i suradnici (1995) vodeći se istim istraživanjem rasizma, razvijaju koncept neoseksizma (engl. neosexism) kojeg definiraju kao „manifestaciju konflikta između egalitarnih vrijednosti koje su društveno propisane i rezidualnih negativnih osjećaja spram žena“" (Tougas i sur., 1995:843). Pojedinci s neoseksističkim stavovima mogu osjećati pritisak zadržavanja liberalnog svjetonazora kako bi izbjegli društvenu stigmatizaciju ili kako bi se osjećali dobro o sebi, što ih prisiljava da svoje predrasude iskazuju u prikrivenom obliku. Primjerice, određeni pojedinac može tvrditi kako podržava rodnu ravnopravnost, a istovremeno ne odobravati mjere namijenjene smanjenju nejednakosti među spolovima (kao što su afirmativna akcija ili plaćeni programi za porodiljni 
dopust) (Huber, 2016). Također, valja istaknuti kako se neoseksizam odnosi i na otpor promjenama statusa žena. Dakle, na suptilan način, ova predrasudna vjerovanja predstavljaju pogled na žene koji ih isključuje iz utjecajnih pozicija u netradicionalnim područjima (npr. politike) (Beaton i sur., 1996).

\subsection{Ambivalentni seksizam}

Oslanjajući se na teoriju ambivalentnog rasizma (Katz i sur., 1986 prema Huber, 2016), Glick i Fiske (1996) suvremeni seksizam promatraju kao posebnu vrstu predrasude koja je prije označena kao duboka ambivalentnost, nego jednolična antipatija. Ambivalentni seksizam (engl. ambivalent sexism) višedimenzionalni je konstrukt koji istovremeno karakteriziraju pozitivni i negativni stavovi spram žena, odnosno dva seta seksističkih stavova: neprijateljski i benevolentni. Srž neprijateljskog seksizma (engl. hostile sexism) je u mizoginiji, dok benevolentni seksizam (engl. benevolent sexism) promatra žene stereotipno u ograničenim rodnim ulogama (Glick i Fiske, 1996; Galić, 2012). No, iako benevolentni seksizam predstavlja svojevrsni subjektivan pozitivan pogled na žene, u kojem su žene okarakterizirane kao primateljice muške zaštite, idealizacije i ljubavi, on zapravo dijeli uobičajene pretpostavke s neprijateljskim seksizmom, poput toga da su žene ograničene na obavljanje uloge domaćice (privatna sfera djelovanja) te da se smatraju „slabijim“ spolom (Glick i Fiske, 1996 i 2011; Huber, 2016).

Glick i Fiske (1996) tvrde kako se ambivalentni seksizam identificira putem triju odrednica odnosa između muškaraca i žena, od kojih svaka ima neprijateljsku i benevolentnu stranu. Te tri odrednice su sljedeće: paternalizam, rodna diferencijacija te heteroseksualnost. Svaka odrednica služi za opravdanje društvenih i bioloških uvjeta koji karakteriziraju odnose između spolova. Paternalizam obilježava odnošenje spram drugih na isti način kako to otac čini sa svojom djecom, a ovakvo shvaćanje može predstaviti seksizam kao ambivalenciju koja istovremeno uključuje konotacije dominacije (dominantni paternalizam), kao i ljubavi i zaštite (protektivni paternalizam). Nadalje, rodna diferencijacija također se može očitovati u dva oblika, odnosno kao kompetitivna rodna diferencijacija koja ističe kako su samo muškarci ti koji imaju osobine potrebne za upravljanje važnim društvenim institucijama, te kao komplementarna rodna diferencijacija koja ženske osobine, poput izražene osjećajnosti i moralnosti, shvaća komplementarnim muškim osobinama hrabrosti i upravljanja. Naposljetku se, isto tako, i heteroseksualnost iskazuje ambivalentno, odnosno kao heteroseksualno neprijateljstvo (seksualna privrženost spram žene ne može se odvojiti od želje za dominacijom nad istom ženom) te heteroseksualna intimnost (muška seksualna motivacija spram žene povezana je sa stvarnom željom za psihološkom bliskošću s istom ženom) (Glick i Fiske, 1996; Conn i sur., 1999).

\section{OSVRT NA POSTOJEĆE SKALE SUVREMENOG SEKSIZMA}

Prije nego se upustimo u predstavljanje postojećih skala suvremenih tipova seksizma, valja istaknuti Skalu stavova prema ženama (engl. Attitudes Toward Women Scale - AWS; Spence i sur., 1973) koja se ističe kao najčešće korišteni internacionalni mjerni instru- 
ment seksizma (Swim i Cohen, 1997). Ispitanici koji postižu više rezultate na ovoj skali od 15 čestica podržavaju različit tretman muškaraca i žena, podržavaju dvostruke standarde u ponašanju muškaraca i žena te vjeruju da žene nisu sposobne obavljati određene zadatke jednako dobro kao muškarci. Dakle, vidljivo je kako ova skala mjeri tradicionalne, očite i otvoreno seksističke stavove. U posljednjem desetljeću dvadesetog stoljeća dolazi do promjena u odgovorima na Skali stavova prema ženama, odnosno uočava se opadanje otvorenih seksističkih vjerovanja (Spence i Hahn, 1997; Swim i Cohen, 1997). Stoga se brojni istraživači okreću ispitivanju novih prikrivenih oblika seksizma, a najznačajnije radove navodimo u nastavku.

\subsection{Skale staromodnog i modernog seksizma}

Swim i suradnice ${ }^{2}$ (1995) smišljaju set tvrdnji koje se odnose na tri ranije iznesene odrednice modernog seksizma, ali im dodaju i set tvrdnji koje se odnose na tradicionalne predrasude prema ženama. Dakle, uvidjevši velike sličnosti između rasizma i seksizma, Swim i suradnice (1995) konstruiraju Skalu staromodnog i modernog seksizma (engl. Old-Fashioned Sexism Scale - OFSS i Modern Sexism Scale - MSS) koje gotovo u potpunosti korespondiraju Skalama staromodnog i modernog rasizma (McConahay, 1986, prema Swim i sur., 1995), to jest koriste se identične čestice tih skala s time da se sintagma „Afro-Amerikanci“ zamjenjuje sintagmom „žene“. Skala staromodnog seksizma sastojala se od pet čestica koje su se odnosile na tradicionalne seksističke stavove, dok se Skala modernog seksizma sastojala od osam čestica koje su korespondirale trima odrednicama modernog seksizma. Autorice su pretpostavile da će odgovori na ova dva seta tvrdnji, premda korelirani, najbolje pristajati dvofaktorskom modelu u konfirmatornoj faktorskoj analizi (engl. Confirmatory factor analysis - CFA), s jednim faktorom koji predstavlja staromodni seksizam te drugim koji predstavlja moderni seksizam. Čestice su procjenjivane na skali slaganja od pet stupnjeva, a viši rezultat na skalama označavao je snažnije tradicionalne, odnosno moderne seksističke stavove. Skale su prvotno ispitivane na uzorku od 682 studenta psihologije. Kao što su autorice i pretpostavile, dvofaktorski model, koji predstavlja odvojene staromodne i moderne predrasude, pristajao je značajno bolje od jednofaktorskog modela. Stoga su Swim i suradnice (1995) odlučile konstruirati dvije skale: Skalu staromodnog seksizma, čiji je iznos interne konzistentnosti, odnosno Cronbachov a koeficijent, iznosio 0,66, te Skalu modernog seksizma, čiji je Cronbachov $\alpha$ koeficijent iznosio 0,84 . Valja napomenuti kako autorice $\mathrm{u}$ istom znanstvenom radu iznose rezultate još jedne studije na 788 studenata psihologije (477 žena i 311 muškaraca) kako bi replicirale ranije navedenu faktorsku analizu. U njoj su dobiveni vrlo slični rezultati pa su autorice zaključile kako su drugom studijom replicirani već dobiveni nalazi (Swim i sur., 1995). Stoga su zaključile kako njihovi rezultati pokazuju da se vjerovanja o ženama mogu raščlaniti u dvije distinktivne i interpretabilne komponente: tradicionalna seksistička vjerovanja o ženama, odnosno staromodni seksizam, te prikri-

\footnotetext{
2 Riječ je o tri žene i jednom muškarcu kao koautoricama/u rada o kojemu je riječ.
} 
vene predrasude spram žena, odnosno moderni seksizam. Osim toga, zbog umjerene povezanosti ovih dviju komponenti ( $\mathrm{r}=0,54)$, autorice zaključuju kako su pojedinci koji iskazuju moderne seksističke stavove skloni iskazivati i tradicionalne seksističke stavove (Swim i sur., 1995).

Swim u suradnji s Cohen (1997) provodi još jedno ispitivanje seksističkih stavova kako bi dodatno provjerila metrijske karakteristike skala koje smo ranije predstavili. U ovoj studiji, uz ranije istaknute skale staromodnog i modernog seksizma, autorice uključuju i Skalu stavova prema ženama. Vođene ranijim istraživanjem, Swim i Cohen (1997) pretpostavile su da će Skala stavova prema ženama s modernim seksizmom biti slično povezana kao što je i Skala staromodnog seksizma, jer se skale stavova prema ženama i staromodnog seksizma odnose na otvoreni, dok se Skala modernog seksizma odnosi na prikriveni ili suptilni seksizam. Studija je provedena na 2753 ispitanika (934 muškarca i 1719 žena), primarno studenata psihologije. Konfirmatorna faktorska analiza podupire ranije iznesenu pretpostavku autorica, odnosno Skala stavova prema ženama i Skala staromodnog seksizma visoko saturiraju na faktoru koji predstavlja otvorena seksistička uvjerenja, a ovaj se faktor distingvira od faktora koji predstavlja moderna seksistička uvjerenja. Stoga, autorice zaključuju kako dvije skale koje tvore prvi faktor mjere isti predmet mjerenja, odnosno otvorene seksističke predrasude. Zbog toga što je Skala stavova prema ženama $(\alpha=0,79)$ imala veću pouzdanost u odnosu na Skalu staromodnog seksizma $(\alpha=0,65)$, savjetovale su kako bi u budućim istraživanjima bilo bolje koristiti Skalu stavova prema ženama. Na kraju su zaključile kako istraživači koji žele mjeriti tradicionalne, otvorene seksističke stavove trebaju koristiti Skalu stavova prema ženama, a oni koji žele mjeriti suvremene, prikrivene seksističke stavove trebaju koristiti Skalu modernog seksizma (Swim i Cohen, 1997).

Morrison i suradnici (1999) ponovno provjeravaju metrijske karakteristike skala koje su konstruirale Swim i suradnice (1995), ističući kako su seksistički stavovi mjereni ovim skalama do tada ispitivani isključivo na studentskoj populaciji te kako je potrebno provjeriti njihovu primjenjivost na dobno reprezentativnijoj populaciji. Stoga na uzorku od 187 ispitanika u rasponu od 16 do 58 godina ispituju metrijske karakteristike Skale staromodnog seksizma i Skale modernog seksizma. Obje skale iskazuju zadovoljavajuće iznose Cronbachovog $\alpha$ koeficijenta $(\alpha=0,68 ; \alpha=0,79)$. Morrison i suradnici (1999) potvrđuju kako Skala staromodnog seksizma mjeri jedan predmet mjerenja, odnosno da se radi o jednodimenzionalnoj skali na kojoj viši rezultat predstavlja tradicionalne seksističke stavove prema ženama. No, ovaj rad ne potvrđuje nalaze Swim i suradnica (1995) i Swim i Cohen (1997) kako Skala modernog seksizma mjeri jedan predmet mjerenja. Dobivena su dva faktora u eksplorativnoj faktorskoj analizi (engl. Exploratory factor analysis - EFA): prvi je okupio čestice koje predstavljaju moderne seksističke stavove prema suvremenoj diskriminaciji žena (npr., č. 1: Diskriminacija žena više nije problem u Kanadi), a drugi čestice koje predstavljaju negativne stavove spram politika koje su stvorene kako bi promovirale rodnu ravnopravnost (npr., č.2: Žene često propuštaju prilike za dobro zaposlenje zbog seksualne diskriminacije). Jedna je čestica isključena iz analize, a to je jedina čestica koja se odnosila na posljednju odrednicu modernog seksizma, od- 
nosno ogorčenje zbog posebnih pogodnosti koje žene dobivaju samo zbog toga što su žene. Stoga su Morrison i suradnici (1999) zaključili kako je Skalu modernog seksizma potrebno rašllaniti na dvije subskale: prva subskala mjeri moderne seksističke stavove prema današnjoj diskriminaciji žena, a druga negativne stavove spram politika koje su osmišljene za promoviranje rodne ravnopravnosti.

\subsection{Skala neoseksizma}

Tougas i suradnici (1995) razvijaju Skalu neoseksizma (engl. Neosexism Scale - NS) koja sadrži 11 čestica koje su djelomično adaptirane iz različitih skala prikrivenog rasizma, a djelomično su konstruirane isključivo za ovu skalu. Adaptirane čestice odnose se na tri odrednice koje čine moderni seksizam (1. nijekanje postojanja daljnje diskriminacije nad ženama; 2. antagonizam spram zahtjeva žena; te 3. ogorčenje zbog posebnih pogodnosti koje žene dobivaju samo zbog toga što su žene), dok se ostale čestice, koje su konstruirane isključivo za ovu skalu, odnose na pitanja vezana uz žensku participaciju u radnoj snazi. Procjenjivano je 11 čestica na skali procjene slaganja od sedam stupnjeva, a viši rezultat na skali označavao je jače neoseksističke stavove (Campbell i sur., 1997). Pouzdanost Skale neoseksizma u prvoj je studiji (uzorak se sastojao od 130 muških studenata psihologije) iznosila $\alpha=0,78$, a u drugoj (uzorak se sastojao od 149 zaposlenika jedne tvrtke) $\alpha=0,76$, odnosno skala je, prema autoricama, iskazivala visok stupanj interne konzistentnosti u obje studije. Dobiven je jedan faktor u eksplorativnoj faktorskoj analizi, to jest skala je mjerila jedan predmet mjerenja (Tougas i sur., 1995). Dodatno, valja istaknuti kako Beaton i suradnici (1996) u vlastitoj studiji, koja se odnosila na neoseksizam među muškim menadžerima $(\mathrm{N}=356)$, koriste Skalu neoseksizma Tougas i suradnika (1995), a u njihovoj studiji Cronbachov $\alpha$ iznosio je 0,71.

\subsection{Skala ambivalentnog seksizma}

Glick i Fiske (1996) razvijaju Skalu ambivalentnog seksizma (engl. The Ambivalent Sexism Inventory - ASI) koja se sastoji od dvije subskale: Subskale neprijateljskog seksizma i Subskale benevolentnog seksizma. Skala se za potrebe znanstvenog rada autora Glick i Fiske (1996) razvijala kroz šest različitih studija (uzoraka) na ukupnom broju od 2250 pojedinaca te je od početnih 140 čestica na kraju konstruirana skala od 22 čestice (11 čestica za svaku subskalu). Česticama je bila pridružena skala procjene slaganja od sedam stupnjeva. Viši rezultati na objema skalama indiciraju stavove koji opravdavaju konvencionalne rodne uloge i odnose. Analiza glavnih komponenata (engl. Principal component analysis - PCA) 22 čestice proizvela je jednu komponentu neprijateljskog seksizma te tri subkomponente benevolentnog seksizma koje su korespondirale trima odrednicama benevolentnog seksizma (protektivni paternalizam, komplementarna rodna diferencijacija i heteroseksualna intimnost). Te tri subkomponente u komponentnoj faktorskoj analizi drugog reda tvorili su jedan faktor benevolentnog seksizma. Obje subskale u svih šest studija imale su zadovoljavajuće iznose Cronbachovog $\alpha$ koeficijenta (Subskala neprijateljskog seksizma: $\alpha$ seže od 0,83 do 0,92; Subskala benevolentnog seksizma: $\alpha$ seže od 0,73 do 0,85 ). 
Do 2011. godine Skala ambivalentnog seksizma validirana je na nekoliko desetaka tisuća ljudi diljem svijeta (Glick i Fiske, 2011). U većini istraživanja koja su koristila ovu skalu povezanost između neprijateljskog i benevolentnog seksizma sezala je od trivijalne do umjereno pozitivne povezanosti što pokazuje kako su ova dva tipa seksizma dva distinktivna konstrukta. Unatoč tome, kroskulturalne usporedbe pokazale su da ako pojedinci unutar određenog društva u prosjeku podržavaju fenomen neprijateljskog seksizma, istovremeno podržavaju i fenomen benevolentnog seksizma, a vrijedi i obrnuto, odnosno ako odbijaju jednu od ideologija, načelno odbijaju i drugu. To potvrđuje pretpostavku Glicka i Fiske (1996) kako ova dva tipa seksizma predstavljaju komplementarnu ideologiju koja se zalaže za rodnu neravnopravnost. Osim toga, autori ističu kako se Skala ambivalentnog seksizma kroskulturalno koristi kao dvokomponentni model, to jest benevolentni se seksizam ne rastavlja na svoje tri odrednice ili subkomponente, već se koristi kao jedan cjeloviti konstrukt (Glick i Fiske, 2011).

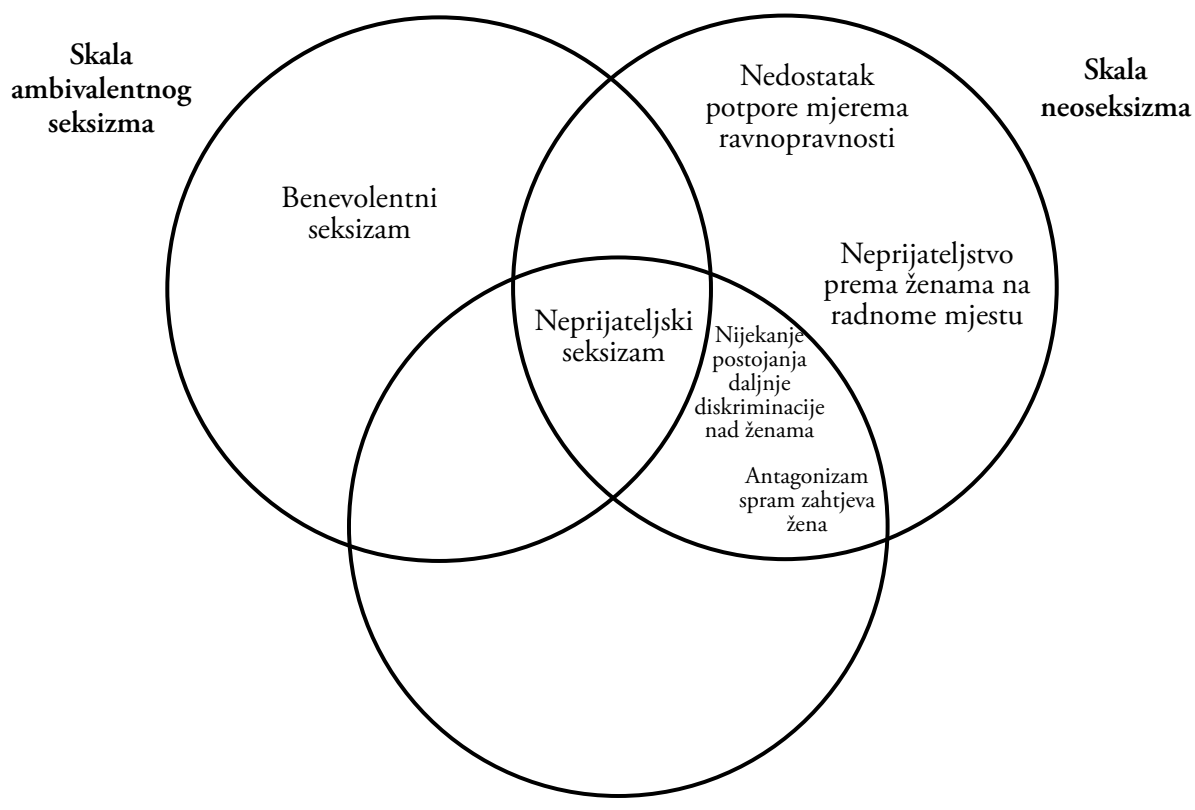

Skala modernog seksizma

Slika 1. Hipotetski prikaz varijance koju dijele Skala modernog seksizma, Skala neoseksizma i Skala ambivalentnog seksizma (prema Huber, 2016:56; vlastiti prijevod)

\subsection{Povezanost suvremenog seksizma s tradicionalnim seksizmom}

Nakon usporedbe triju skala suvremenih tipova seksizma, valja istaknuti i njihove povezanosti s različitim tradicionalnim oblicima seksizma kako bismo dobili uvid u utvrđene korelacije ovih dvaju oblika seksizma (vidi Tablicu 1), što će nam pomoći u kasnijoj procjeni konstruktne valjanosti vlastite Skale suvremenog seksizma. 
Swim i suradnice (1995) navode kako je povezanost između Skale modernog seksizma i Skale staromodnog seksizma iznosila $\mathrm{r}=0,51 \mathrm{u}$ prvoj studiji, a r=0,47 u drugoj. Povezanost ovih dviju skala u istraživanju Conn i suradnika (1999) iznosila je r=0,39. Zatim, Tougas i suradnici (1995) ističu kako je povezanost između Skale neoseksizma i Skale staromodnog seksizma iznosila r=0,64. Nadalje, Glick i Fiske (1996) svoju Skalu ambivalentnog seksizma povezuju s dvije mjere tradicionalnog seksizma: Skalom staromodnog seksizma $(\mathrm{r}=0,42)$ te Skalom stavova prema ženama $(\mathrm{r}=0,63)$. Osim toga, obje skale tradicionalnog seksizma povezali su i s obje subskale ambivalentnog seksizma. Povezanost Subskale neprijateljskog seksizma i Skale staromodnog seksizma iznosila je $\mathrm{r}=0,48$, a povezanost iste subskale i Skale stavova prema ženama $\mathrm{r}=0,68$. Povezanosti Subskale benevolentnog seksizma s obje mjere tradicionalnog seksizma su ipak slabije te su iznosile $r=0,24$, odnosno $\mathrm{r}=0,40$. Conn i suradnici (1999) navode iznose povezanosti obiju subskala ambivalentnog seksizma sa Skalom staromodnog seksizma te je povezanost Subskale neprijateljskog seksizma i Skale staromodnog seksizma iznosila $\mathrm{r}=0,51$, a povezanost Subskale benevolentnog seksizma i iste skale tradicionalnog seksizma je ponovno bila slabija i iznosila je $\mathrm{r}=0,27$. Navedene studije, ali i još neke dodatne (vidi reference u Tablici 1), pokazuju kako Skala modernog seksizma, Skala neoseksizma i Subskala neprijateljskog seksizma imaju pozitivne i umjerene korelacije $s$ različitim skalama tradicionalnog seksizma, dok Subskala benevolentnog seksizma s istim skalama ipak ima nešto slabije pozitivne korelacije, tj. korelacije koje su niskog iznosa.

Tablica 1. Usporedba Cronbachovih ( $\alpha$ ) koeficijenata pouzdanosti skala suvremenih tipova seksizma te njihovih povezanosti $(r)$ s relevantnim skalama

\begin{tabular}{|c|c|c|c|c|c|}
\hline $\begin{array}{l}\frac{0}{\text { जี }} \\
\frac{y}{\infty} \\
\cdot \frac{Z}{N} \\
\text { Z }\end{array}$ & 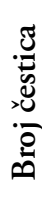 & 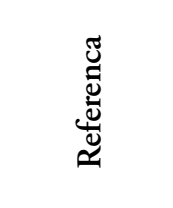 & 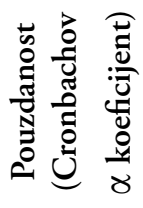 & 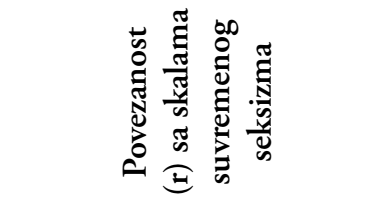 & 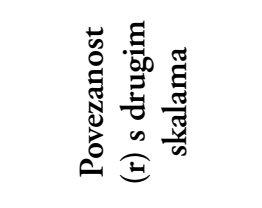 \\
\hline \multirow{6}{*}{ 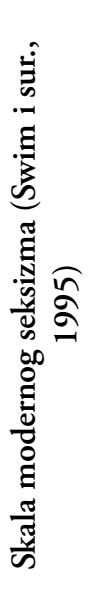 } & \multirow{6}{*}{8} & $\begin{array}{c}\text { Swim i sur., } \\
1995\end{array}$ & 0,84 & & $\begin{array}{l}\mathrm{r} \text { (Skala staromod. } \\
\text { seks.) }=0,47-0,51\end{array}$ \\
\hline & & $\begin{array}{c}\text { Glick i } \\
\text { Fiske, } 1996\end{array}$ & & $\begin{array}{l}\mathrm{r}(\text { Subskala nep. seks. })=0,65 \\
\mathrm{r}(\text { Subskala ben. seks. })=0,33\end{array}$ & \\
\hline & & $\begin{array}{c}\text { Swim i } \\
\text { Cohen, } \\
1997\end{array}$ & 0,82 & $\mathrm{r}($ Skala neoseks. $)=0,59$ & \\
\hline & & $\begin{array}{l}\text { Campbell i } \\
\text { sur., } 1997\end{array}$ & 0,65 & & $\begin{array}{c}\mathrm{r}(\text { Skala stavova } \\
\text { prema fem. pok. })= \\
-0,53\end{array}$ \\
\hline & & $\begin{array}{c}\text { Conn i sur., } \\
1999 \\
\end{array}$ & 0,82 & $\begin{array}{l}\mathrm{r}(\text { Subskala nep. seks. })=0,52 \\
\mathrm{r}(\text { Subskala ben. seks. })=0,17\end{array}$ & $\begin{array}{c}\mathrm{r}(\text { Skala staromod. } \\
\text { seks. })=0,39\end{array}$ \\
\hline & & $\begin{array}{l}\text { Morrison i } \\
\text { sur., } 1999\end{array}$ & 0,79 & & \\
\hline
\end{tabular}




\begin{tabular}{|c|c|c|c|c|c|}
\hline \multirow{4}{*}{ 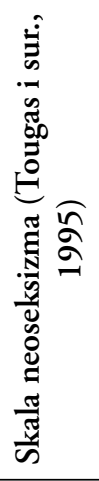 } & \multirow{4}{*}{11} & $\begin{array}{c}\text { Tougas i } \\
\text { sur., } 1995\end{array}$ & $0,76-0,78$ & & \\
\hline & & $\begin{array}{c}\text { Beaton i } \\
\text { sur., } 1996\end{array}$ & 0,71 & & \\
\hline & & $\begin{array}{l}\text { Campbell i } \\
\text { sur., } 1997\end{array}$ & 0,81 & $\mathrm{r}($ Skala mod. seks. $)=0,59$ & $\begin{array}{c}\mathrm{r}(\text { Skala stavova } \\
\text { prema fem. pok.) } \\
-0,52\end{array}$ \\
\hline & & $\begin{array}{c}\text { Masser i } \\
\text { Abrams, } \\
1999\end{array}$ & $0,62-0,85$ & $\begin{array}{c}\mathrm{r}(\text { Subskala nep. seks. })=0,52- \\
0,81 \\
\mathrm{r}(\text { Subskala ben. seks. })=0,22- \\
0,48\end{array}$ & \\
\hline \multirow{3}{*}{ 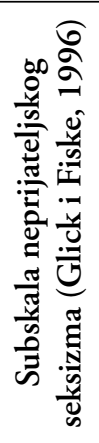 } & \multirow{3}{*}{11} & $\begin{array}{c}\text { Glick i } \\
\text { Fiske, } 1996\end{array}$ & $0,83-0,92$ & $\mathrm{r}($ Skala mod. seks. $)=0,65$ & $\begin{array}{c}\mathrm{r}(\text { Skala staromod. } \\
\text { seks. })=0,48 \\
\mathrm{r}(\text { Skala stavova } \\
\text { prema ženama })= \\
0,68\end{array}$ \\
\hline & & $\begin{array}{c}\text { Conn i sur., } \\
1999\end{array}$ & 0,88 & $\mathrm{r}($ Skala mod. seks. $)=0,52$ & $\begin{array}{c}\mathrm{r}(\text { Skala staromod } \\
\text { seks. })=0,51\end{array}$ \\
\hline & & $\begin{array}{l}\text { Masser i } \\
\text { Abrams, } \\
1999\end{array}$ & $0,75-0,88$ & $\mathrm{r}($ Skala neoseks. $)=0,52-0,81$ & \\
\hline \multirow{3}{*}{ 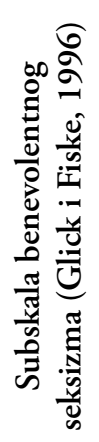 } & \multirow{3}{*}{11} & $\begin{array}{c}\text { Glick i } \\
\text { Fiske, } 1996\end{array}$ & $0,73-0,85$ & $\mathrm{r}($ Skala mod. seks. $)=0,33$ & $\begin{array}{c}\mathrm{r}(\text { Skala staromod. } \\
\text { seks. })=0,24 \\
\mathrm{r}(\text { Skala stavova } \\
\text { prema ženama })= \\
0,40\end{array}$ \\
\hline & & $\begin{array}{c}\text { Conn i sur., } \\
1999 \\
\end{array}$ & 0,76 & $\mathrm{r}($ Skala mod. seks. $)=0,17$ & $\begin{array}{c}\mathrm{r} \text { (Skala staromod } \\
\text { seks. })=0,27\end{array}$ \\
\hline & & $\begin{array}{c}\text { Masser i } \\
\text { Abrams, } \\
1999\end{array}$ & $0,61-0,83$ & $\mathrm{r}($ Skala neoseks. $)=0,22-0,48$ & \\
\hline
\end{tabular}

\subsection{Povezanost suvremenog seksizma sa stavovima prema feminističkom pokretu}

$S$ obzirom na to da je primarni cilj svih feminističkih pokreta postizanje rodne ravnopravnosti, logično je za očekivati negativnu vezu između podržavanja feminističkog pokreta i sklonosti suvremenim oblicima seksizma (vidi Tablicu 1), tj. očekuje se da su pozitivni stavovi prema feminističkom pokretu popraćeni niskom razinom podržavanja ili pak odbacivanjem uvjerenja karakterističnih za suvremene seksističke stavove (Campbell i sur., 1997). U istraživanju Campbell i suradnika (1997) u Kanadi, Skala stavova prema feminističkom pokretu bila je podjednako i to umjereno negativno povezana kako sa Skalom modernog seksizma Swim i suradnica (1995) (r=-0,53), tako i sa Skalom neoseksizma Tougas i suradnika (1995) $(r=-0,52)$ što je potvrdilo pretpostavku da 
su osobe koje iskazuju moderne seksističke ili neoseksističke stavove istovremeno manje sklone podržavati feministički pokret. Stoga u validaciji novokonstruirane skale suvremenog seksizma u ovoj studiji također očekujemo utvrđivanje negativne umjerene veze sa Skalom stavova prema feminističkom pokretu.

\subsection{Skale tradicionalnog i suvremenog tipa seksizma korištene u Hrvatskoj}

Suvremeni oblici seksizma u hrvatskoj su sociologiji mjereni tek u nekoliko navrata (Galić i Nikodem, 2006; Čulig i sur., 2007; Galić, 2008 i 2012; Galić i Klasnić, 2012; Klasnić i Štulhofer, 2018), a kada su i bili mjereni, obično nisu mjereni samostalno već zajedno s različitim tradicionalnim oblicima (uz iznimku Klasnić i Štulhofer, 2018). U nastavku ćemo istaknuti ključne recentne radove u hrvatskoj sociološkoj misli koji su se odnosili na ispitivanje tradicionalnih i suvremenih seksističkih stavova.

Čulig i suradnici (2007) u istraživanju o odnosu građana Hrvatske prema pridruživanju Republike Hrvatske Europskoj Uniji koristili su mjerni instrument Likertova tipa od deset čestica namijenjen mjerenju tradicionalnog (rigidnog) i modernog (perfidnog) seksizma, a ispitanicima je za procjenu ponuđena peterotomna ordinalna skala slaganja. Interpretacija mjerne skale provedena je isključivo na muškim ispitanicima $(\mathrm{N}=474)$. Faktorskom analizom ${ }^{3}$ dobivena su dva faktora nazvana tradicionalni seksizam te moderni seksizam, čija je povezanost bila umjerena i iznosila je $r=0,46$, ali je sadržaj pojedinih faktora bio jasno razlučiv. ${ }^{4}$ Valja napomenuti kako je instrument modernog seksizma autora Čuliga i suradnika (2007) (uz određene preinake, tj. njegovo skraćivanje) korišten u studiji Klasnić i Štulhofera (2018) na uzorku učenika zagrebačkih srednjih škola (136 mladića i 326 djevojaka). U ovoj studiji je konstrukt kojeg Čulig i suradnici (2007) nazivaju moderni seksizam nazvan neoseksizam te je predstavljen kao latentni konstrukt odmjeren $s$ četiri čestice, a njegova je pouzdanost bila prihvatljiva u oba poduzorka ( $\alpha$ za djevojke $=0,74, \alpha$ za mladiće $=0,77)$ (Klasnić i Štulhofer, 2018).

Galić (2008 i 2012) polazi od pretpostavke kako su koncepti patrijarhalnog i rodno egalitarnog društva u svijesti ispitanika međusobno suprotstavljeni. Stoga, autorica razvija instrument od 17 čestica kojim su operacionalizirani koncepti tradicionalnog i modernog seksizma kao vjerojatni smjerovi kretanja hrvatskog društva u smislu razvoja rodnog identiteta. Instrument je korišten u istraživanju koje je provedeno 2004. godine na reprezentativnom uzorku građana Republike Hrvatske veličine 1.202 ispitanika. Česticama je bila pridružena skala procjene slaganja od pet stupnjeva, a analiza glavnih komponenata rezultirala je $s$ četiri komponente. Prva je komponenta nazvana antropološki patrijarhalizam, druga deklarativni egalitarizam, treća androcentrizam s inverzijom žrtva / nasilnik te četvrta za rodno egalitarno društvo. Međusobne korelacije komponentni pokazale su pozitivnu korelaciju prve i treće komponente, uz njihovu negativnu korelaciju s četvrtom komponentnom kojom se iskazuje potreba ukidanja patrijarhata

3 Nije navedena koja vrsta faktorske analize je korištena.

4 Čulig i suradnici (2007) ne ističu kolika je pouzdanost mjernih instrumenata. 
i potreba za rodno egalitarnim društvom. U istraživanju na reprezentativnom uzorku od 1.008 ispitanika 2010. godine Galić (2012) koristi isti instrument, a ovoga su puta ekstrahirane 3 komponente koje su opisale sljedeće latentne dimenzije seksističkih koncepata: androcentrizam, patrijarhalizam te rodni egalitarizam. ${ }^{5}$ Potvrden je nalaz ranijeg istraživanja iz 2004. godine o nespojivosti seksističkih koncepata društva (antropocentrizma i patrijarhalizma) s konceptom rodne društvene jednakosti. Valja napomenuti kako je instrument autorice Galić (uz određene preinake, tj. njegovo skraćivanje) korišten u još nekoliko navrata (Galić i Nikodem, 2006; Galić i Klasnić, 2012; Klasnić, 2014) u kojima se, najvjerojatnije zbog različitog broja čestica u pojedinom mjerenju, njihove faktorske strukture nešto razlikuju.

Navedeni prikazi korištenih skala u inozemnom i domaćem kontekstu ukazuju na određene metodološke i konceptualne nedostatke u mjerenju suvremenog seksizma. Naime, iako postoji više različitih skala koje proizlaze iz donekle bliskih, ali ipak međusobno različitih konceptualnih modela i koje se radi toga međusobno djelomično sadržajno preklapaju, uviđamo kako postoji potreba da se istraživačima društvenih znanosti zainteresiranima za proučavanje suvremenog seksizma ponudi jedna pragmatična opcija za njegovo mjerenje. Čini se kako je ova potreba posebno izražena na domaćoj istraživačkoj sceni gdje uviđamo konceptualne nedoumice autora u izjednačavanju različitih modela suvremenog seksizma. Tako primjerice Galić (2012) ne razlikuje moderni seksizam i neoseksizam, dok Klasnić i Štulhofer (2018) neoseksizam mjere konstruktom kojeg Čulig i suradnici (2007) nazivaju moderni seksizam.

Stoga je cilj ove studije konstruirati i evaluirati novu mjernu skalu koja će objediniti različite oblike suvremenog seksizma, a koju će istraživačice i istraživači u društvenim znanostima moći koristiti u anketnim istraživanjima koja se bave temama rodne neravnopravnosti i diskriminacije žena. Dodatni doprinos ovog rada proizlazi iz predstavljene konceptualne distinkcije različitih oblika suvremenog seksizma. Takva iscrpna konceptualizacija različitih manifestacija suvremenog seksizma olakšava razvoj mjerne skale kojoj je cilj sadržajno obuhvatiti što veći broj tema relevantnih za istraživanje fenomena suvremenog seksizma.

\section{KONCEPTUALNO-OPERACIONALNA RAZRADA NOVE SKALE SUVREMENOG SEKSIZMA}

Suvremeni seksistički stavovi odnose se na odobravanje suvremenih diskriminatornih i predrasudnih stavova o ženama u privatnoj i javnoj sferi njihova djelovanja. Oni obično ostaju prikriveni, suptilni i nezapaženi te u odnosu na tradicionalna seksistička uvjerenja, podliježu znatno slabijoj društvenoj osudi. Suvremeni se seksizam, kako ga definiramo u ovoj studiji, konceptualno sastoji od četiri temeljne sadržajne domene: nijekanje postojanja daljnje diskriminacije nad ženama, antagonizam spram zahtjeva žena,

\footnotetext{
5 Niti u ovome radu, kao što je to bio slučaj kod Čuliga i suradnika (2007), nisu istaknuti koeficijenti pouzdanosti mjernih instrumenata.
} 
ogorčenje zbog posebnih pogodnosti koje žene dobivaju samo zbog toga što su žene te zamjeranje ženama zbog „preosjetljivosti“ na seksizam i seksualno uznemiravanje. Prve tri domene korespondiraju trima odrednicama modernog seksizma (Swim i sur., 1995) i neoseksizma (Tougas i sur., 1995) te djelomično neprijateljskom (hostilnom) seksizmu (Glick i Fiske, 1996). Posljednja, četvrta domena koja se odnosi na "preosjetljivost“ žena na seksističke verbalne i fizičke postupke ovdje je uvrštena od strane autora ovog rada. Teme koje se odnose na ovu domenu do sad su se samo sporadično pronalazile u česticama pojedinih skala suvremenih oblika seksizma (Glick i Fiske, 1996; Čulig i sur., 2007), iako nisu bile konceptualizirane kao njegove zasebne sadržajne domene. Naša konceptualna razrada odvijala se tijekom 2017. godine, za vrijeme uspona MeToo pokreta u Americi, kada teme seksualnog uznemiravanja žena počinju puniti medijski prostor i u Hrvatskoj. Autori su tada svjedočili različitim negativnim reakcijama na ovaj pokret u kojima se posebno isticao argument ženske preosjetljivosti na seksizam i seksualno uznemiravanje, što je također bio poticaj za uključivanje ove tematike kao zasebne domene suvremenog seksizma. Njezinu relevantnost kasnije potvrđuju i nalazi Gallupova istraživanja iz 2019. godine koje nakon uspona MeToo pokreta ukazuje na porast udjela Amerikanaca koji smatraju da su ljudi preosjetljivi na seksualno uznemiravanje na radnom mjestu (Brenan, 2019).

Nijekanje postojanja daljnje diskriminacije žena kako u hrvatskom, tako i općenito u suvremenom društvu, prva je sadržajna doma suvremenog seksizma u našoj studiji. Ova se domena odnosi na mišljenje kako su žene i muškarci danas posve ravnopravni i jednako tretirani u društvu, kako u javnoj, tako i u privatnoj sferi djelovanja. U javnoj sferi djelovanja ova domena zahvaća fenomene rodne ravnopravnosti, pravednosti sustava zapošljavanja i tržišta rada, jednakih plaća za muškarce i žene te jednakih mogućnosti za uspjeh muškaraca i žena u gospodarstvu i politici. $S$ druge strane, u privatnoj se sferi djelovanja odnosi na suptilno odbacivanje ravnopravnosti u raspodjeli obiteljskih poslova koji se tiču odgoja i brige za djecu te na koncept pomaganja muškaraca u obavljanju kućanskih poslova koji je u suprotnosti $s$ konceptom ravnopravne raspodjele kućanskih poslova između muškarca i žene koji žive u zajedničkom kućanstvu.

Druga se domena odnosi na antagonizam spram zahtjeva žena, odnosno antagonizam spram ženskog aktivnog zahtijevanja određenih prava. Ova se domena dakle primarno odnosi na nezadovoljstvo zahtjevima kojima žene aktivno traže ostvarenje svojih prava putem različitih političkih i civilnih organizacija i institucija. Kao i sadržaji u prvoj domeni, i sadržaji koji čine ovu domenu mogu se odnositi na obje sfere djelovanja žena. U najvećoj se mjeri odnose na traženje različitih prava i zahtjeva koji poboljšavaju položaj žena na radnom mjestu i u političkom djelovanju, no također i u obiteljskoj sferi s ciljem postizanja potpune rodne ravnopravnosti.

Treća se domena odnosi na ogorčenje zbog posebnih pogodnosti koje žene dobivaju samo zbog toga što su žene. Za razliku od druge domene u kojoj žene aktivno traže određena prava, u ovoj se domeni na žene gleda kao na pasivne korisnice pogodnosti i usluga koje su već ostvarene u društvu zahvaljujući ženskim emancipatorskim naporima. Također se odnosi na obje sfere djelovanja (privatnu i javnu), a najznačajnije teme koje obilje- 
žavaju ovu sadržajnu domenu su pretjerano posvećivanje pažnje vlasti i medija ženskim zahtjevima i problemima (poput nasilja nad ženama) te nepravednost politika rodne ravnopravnosti prema muškarcima.

Posljednja, četvrta domena se odnosi na zamjeranje ženama zbog "preosjetljivosti“ na seksizam, kao i na seksualno uznemiravanje. Ova se domena primarno odnosi na privatnu sferu djelovanja žena, to jest na interpersonalne odnose koje žene uspostavljaju u svome životu. No, također, valja istaknuti kako se ti odnosi mogu iskazati i u javnoj sferi, posebice u interpersonalnim odnosima na poslu. Pojam preosjetljivosti u nazivu ove sadržajne domene naveden je pod navodnim znacima jer se time označava kako suvremeni seksistički stavovi u ovoj domeni umanjuju stvarne negativne posljedice rodne neravnopravnosti i diskriminacije žena. Osjetljivost žena na neprimjerene verbalne komentare, nezadovoljstvo zbog primoranosti muškaraca na oprez u izražavanju kako ih se ne bi proglasilo seksistima te „suviše olaka“ karakterizacija nekog djelovanja kao seksualnog uznemiravanja čine srž ove sadržajne domene.

$\mathrm{Na}$ temelju opisanih sadržaja, svaka je domena operacionalizirana u niz indikatora u javnoj i u privatnoj sferi (vidi Prilog 1). Strategija za odabir i osmišljavanje čestica skale za svaki pojedini indikator oslanjala se na deduktivan proces utemeljen na predstavljenoj konceptualizaciji suvremenog seksizma, pri čemu smo nastojali obuhvatiti i čestice koje se odnose isključivo na javnu ili na privatnu sferu, ali, tamo gdje je to bilo moguće, i na one čestice koje se odnose na obje sfere istovremeno. Nakon što su iz postojećih mjernih instrumenata probrane čestice koje svojim sadržajem najbolje odgovaraju indikatorima, preostale čestice za one indikatore koje nismo uspjeli pokriti postojećim česticama, osmišljene su od strane autora ovog rada.

Treba još napomenuti kako se suvremeni seksizam vrlo vjerojatno može manifestirati i na drugim mnogo manje istraženim područjima koje ova konceptualizacija, pa niti sama skala, nema ambicije u potpunosti obuhvatiti. Primjerice, teme vezane za reproduktivne prakse, prava i statuse žena, poput stavova o dojenju, samohranom majčinstvu, pobačaju i sl. zasigurno imaju svoje diskriminatorne i predrasudne oblike koji ovdje nisu obuhvaćeni. U skladu s dosadašnjim spoznajama o suvremenom seksizmu, posebice oslanjajući se na koncepte modernog i neoseksizma, pretpostavili smo kako četiri navedene sadržajne domene tvore jednodimenzionalni predmet mjerenja - suvremeni seksizam. Također, na temelju navedenih spoznaja o prirodi odnosa suvremenog seksizma sa spolom, tradicionalnim seksističkim stavovima i stavovima prema feminističkom pokretu, rad počiva na jednoj osnovnoj i dvije izvedene hipoteze. Osnovna hipoteza ove studije jest da se suvremeni seksistički stavovi mogu u velikom dijelu protumačiti spolom, tradicionalnim seksističkim stavovima i stavovima prema feminističkom pokretu. Izvedene hipoteze, iz kojih su razvidni smjerovi pretpostavljenih odnosa, su sljedeće:

1. Muškarci postižu više rezultate na skali suvremenog seksizma od žena, čak i kad se isključi utjecaj tradicionalnog seksizma i stavova o feminističkom pokretu.

2. Suvremeni seksistički stavovi pozitivno su povezani $s$ tradicionalnim seksističkim stavovima, a negativno sa stavovima o feminističkom pokretu, kako na objedinjenom uzorku tako i na poduzorcima muškaraca i žena zasebno. 
Kod konstrukcije i evaluacije nove skale posebnu pozornost treba posvetiti procjeni valjanosti skale. Moderni pristupi valjanosti navode istovremenu potrebu za racionalnim i empirijskim dokazima valjanosti, ali ne postoji univerzalni obrazac za dokazivanje valjanosti. Prema klasičnoj teoriji mjerenja ne govori se o univerzalnoj valjanosti nekog testa ili instrumenta, već o valjanosti njegove upotrebe u određenu svrhu. Da bi nešto bilo valjano, mora biti zadovoljen uvjet pouzdanosti, ali sama pouzdanost ne uvjetuje i valjanost (Rupp i Pant, 2007). Premda postoje brojne klasifikacije vrsta valjanosti, najčešće se govori o tri različita, iako u velikoj mjeri povezana, koncepta valjanosti (Touliatos i sur., 1990): 1. sadržajna valjanost; 2 . kriterijska valjanost te 3 . konstruktna valjanost. Sadržajna (engl. content-based) valjanost je vrsta valjanosti koja ispituje koliko dobro su u nekoj skali uzorkovane i zastupljene čestice nekog univerzuma mjerenja. Odnosi se na sadržaj i relevantnost pojedinih čestica za mjerenje željenog predmeta mjerenja (Touliatos i sur., 1990). U ovoj studiji sadržajna valjanost Skale suvremenog seksizma (SSS) razmatrat će se u obliku diskusije o sadržaju čestica u odnosu na konceptualnu razradu predmeta mjerenja, prethodno korištene validirane skale za mjerenje modernog seksizma i neoseksizma, sadržaje koje ova skala uvodi kao novitet u odnosu na postojeće skale te sadržaje koji su zbog isključivanja pojedinih čestica uklonjeni iz završne inačice skale. Kriterijska (engl. criterion-based) valjanost odnosi se na to koliko je skala povezana s drugim vanjskim kriterijima, često u smislu tzv. istodobne valjanosti (engl. concurrent validity), tj. očekivanih povezanosti $s$ drugim skalama i razlika u prosjecima grupa ili u smislu prediktivne valjanosti, tj. procjene korelira li mjerenje u jednoj vremenskoj točki s mjerenjem u drugoj vremenskoj točki (Touliatos i sur., 1990). U ovoj studij kriterijska valjanost SSS-a procijenit će se na temelju razlike u rezultatima prema spolu (tzv. valjanost poznatih grupa ili engl. known-groups validity, prema Spector, 1992), pri čemu se očekuju viši rezultati muškaraca nego žena.

Konstruktna (engl. construct-based) valjanost najvažniji je i najsloženiji oblik valjanosti. To je vrsta valjanosti koja ispituje koliko dobro skala odražava inherentni konstrukt. Skala mora korelirati s bliskim konceptima (konvergentna valjanost), a ne smije korelirati $s$ konceptima koji s njom nisu povezani (diskriminativna valjanost) ${ }^{6}$ (Touliatos i sur., 1990). Konvergentna valjanost u ovoj studiji procijenit će se na način da ćemo rezultate na SSS-u povezati s rezultatima na Skali tradicionalnog seksizma (STS) i Skali stavova prema feminističkom pokretu (SSFP) pri čemu na temelju prethodnih istraživanja (Swim i sur., 1995; Tougas i sur., 1995; Campbell i sur., 1997; Conn i sur., 1999) očekujemo umjerenu pozitivnu vezu s tradicionalnim seksizmom i umjerenu negativnu vezu sa stavovima o feminističkom pokretnu. Konstruktna valjanost također se povezuje i s faktorskom valjanošću u smislu da faktorska analiza mora pokazati onoliko dimenzija koliko smo konceptualno predvidjeli pri čemu očekujemo da će SSS biti jednodimenzionalan. Treba naglasiti da jedna studija ne može u potpunosti dokazati konstruktnu

6 Diskriminativna valjanost, kako je definiraju Touliatos i sur. (1990), u ovoj studiji nije mogla biti testirana jer nije mjeren konstrukt za kojeg bi se očekivala nepovezanost s SSS. 
valjanost, već se ona dokazuje kontinuiranim procesom evaluacije, reevaluacije, dorađivanja i razvoja skale (Touliatos i sur., 1990).

\section{METODOLOGIJA}

\subsection{Uzorak i provedba istraživanja}

Istraživanje je provedeno metodom ankete tehnikom online anketiranja na prigodnom uzorku studenata i studentica Sveučilišta u Zagrebu. ${ }^{7} \mathrm{Za} \mathrm{izradu} \mathrm{online} \mathrm{anketnog} \mathrm{upitni-}$ ka i prikupljanje podataka korišten je alat LimeSurvey. Prije provedbe procesa prikupljanja podataka zatražena je i dobivena dopusnica Povjerenstva Odsjeka za sociologiju za prosudbu etičnosti istraživanja Filozofskog fakulteta Sveučilišta Zagrebu (broj odluke: 2017-24). Prikupljanje podataka provedeno je tijekom lipnja i srpnja 2017. godine. Poziv na sudjelovanje $\mathrm{u}$ istraživanju s poveznicom na pristup anketnom upitniku distribuiran je putem društvene mreže Facebook u grupe koje okupljaju studentice i studente različitih fakulteta Sveučilišta u Zagrebu. ${ }^{8}$

Prikupljena su 402 valjano ispunjena anketna upitnika. Struktura studenata i studentica u uzorku bila je sljedeća: $74 \%$ bile su ispitanice ženskog spola; $47 \%$ su studenti i studentice preddiplomskog, 36\% diplomskog, a 17\% integriranog studija. Što se tiče znanstvenog područja studiranja, $11 \%$ su studenti i studentice iz područja prirodnih znanosti, $23 \%$ tehničkih znanosti, 14\% biomedicinskih i biotehničkih znanosti, 35\% društvenih znanosti te $17 \%$ humanističkih znanosti. Prema regionalnoj pripadnosti (varijabla kreirana na temelju izjašnjavanja studenata o županiji u kojoj su proveli najveći dio svojeg života) najzastupljeniji su ispitanici iz Grada Zagreba i Zagrebačke županije (50\%), potom oni iz Sjeverne Hrvatske (16\%) i Dalmacije (13\%), dok su ostali ispitanici iz Like, Pokuplja i Banovina (7\%), Slavonije (7\%), Istre, Primorja i Gorskog kotara $(6 \%)$ te inozemstva $(<1 \%)$. Dakle, unatoč prigodnom uzorkovanju putem društvenih mreža, uspjeli smo uzorkom obuhvatiti studente i studentice različitih razina studija, područja studiranja te regionalnih pripadnosti. No, valja naglasiti kako postoje određena odstupanja strukture našeg uzorka od strukture populacije studenata koji pohađaju Sveučilište u Zagrebu, ${ }^{9}$ odnosno gotovo tri četvrtine našeg uzorka čine studentice, preko

\footnotetext{
$7 \mathrm{~S}$ obzirom na to da je istraživanje provedeno na prigodnom uzorku, valja imati na umu da pojedini zaključci nisu reprezentativni za cijelu populaciju studenata i studentica Sveučilišta u Zagrebu, ali mogu ukazivati na određene trendove i pravilnosti u odnosima između koncepata od interesa.

8 Poziv je poslan u sljedeće grupe na društvenoj mreži Facebook: grupe studentskih domova u Zagrebu, grupe studenata pojedinih godina određenih fakulteta te grupe za traženje studentskih poslova u Zagrebu. 9 Struktura studenata Sveučilišta u Zagrebu u 2020. godini prema dostupnoj statistici ISVU sustava: 40\% muškaraca i $60 \%$ žena; $46 \%$ pohađa preddiplomsku razinu studija, $24 \%$ diplomsku razinu studija i $30 \%$ integrirani studij; $10 \%$ pohađa studije iz znanstvenog područja prirodnih znanosti, $44 \%$ tehničkih znanosti, 24\% biomedicinskih i biotehničkih znanosti, $20 \%$ društvenih znanosti te $2 \%$ humanističkih znanosti; regionalna pripadnost - Grad Zagreb i Zagrebačka županija (51\%), Sjeverna Hrvatska (17\%), Dalmacija (13\%) Lika, Pokuplje i Banovina (7\%), Slavonija (7\%), Istra, Primorje i Gorski kotar (5\%).
} 
jedne trećine pohađa diplomsku razinu studija, te preko polovice pohađa područja društvenih i humanističkih znanosti.

\subsection{Mjerni instrumenti}

\subsubsection{Skala suvremenog seksizma}

Za potrebe ove studije konstruiran je mjerni instrument nazvan Skala suvremenog seksizma koji je inicijalno sadržavao 29 čestica. Veći rezultat na skali označava viši stupanj iskazivanja suvremenih seksističkih stavova. Pojedinim česticama pridružena je ordinalna skala procjene slaganja od pet stupnjeva: 1 - „Uopće se ne slažem“; 2 - „Ne slažem se“; 3 - „Niti se slažem, niti se ne slažem“; 4 - Slažem se; 5 - „U potpunosti se slažem“. Ovakvom je skalom moguće mjeriti i intenzitet, a ne samo smjer stava ispitanika prema predmetu mjerenja. Od ukupno 29 čestica, 23 čestice formulirane su pozitivno, odnosno u prilog iskazivanju suvremenih seksističkih stavova, a 6 u negativnom smjeru. $U$ skladu $s$ vlastitom konceptualno-operacionalnom razradom fenomena suvremenog seksizma, početna inačica SSS-a konstruirana je pomoću četiri temeljne sadržajne domene i njihovih odgovarajućih indikatora: 1. nijekanje postojanja daljnje diskriminacije žena (12 čestica); 2. antagonizam spram zahtjeva žena (6 čestica); 3. ogorčenje zbog posebnih pogodnosti koje žene dobivaju samo zbog toga što su žene (8 čestica); te 4. zamjeranje ženama zbog "preosjetlivosti" na seksizam i seksualno uznemiravanje (3 čestice). Dio čestica su djelomično ili u potpunosti preuzete te dio njih djelomično prilagođene iz postojećih skala (dvije od Swim i sur., 1995; četiri od Tougas i sur., 1995; jedna od Glick i Fiske, 1996; dvije od Ekehammar i sur., 2000; pet od Čulig i sur., 2007 te dvije od Galić, 2012), dok su preostale (njih 13) osmislili autori ovog rada. Pojedini indikatori prema domenama i pripadajuće čestice prikazani su u Prilogu 1.

\subsubsection{Skala tradicionalnog seksizma (STS)}

Skala tradicionalnog seksizma korištena u ovoj studiji sastojala se od 12 čestica, a nastala je adaptacijom već postojećih skala staromodnog ili tradicionalnog seksizma nekolicine autora (Swim i sur., 1995; Ekehammar i sur., 2000; Čulig i sur., 2007; Galić, 2012). STS se primarno oslanja na konceptualno-operacionalnu razradu koju koristi Galić (2012), a odnosi se na dvije sadržajne domene: patrijarhalizam ${ }^{10}$ (četiri čestice) i androcentrizam ${ }^{11}$ (osam čestica). Česticama je bila pridružena ordinalna skala procjene slaganja od pet stupnjeva, a veći rezultat na skali označava viši stupanj iskazivanja tradicionalnih seksističkih stavova. Iako je analiza glavnih komponenata dala dvije kompo-

10 Sadržajna domena tradicionalnog seksizma nazvana patrijahalizam odnosi se na patrijarhalni pogled na svijet, a to su: glavni smisao ženina života je majčinstvo, nesposobnost muškaraca da se brinu o djeci jednako dobro i pažljivo kao žene te ženska briga o tipičnim ženskim poslovima oko djece, muža i kuće. 11 Sadržajna domena tradicionalnog seksizma nazvana androcentrizam odnosi se na rodne predrasude poput onih da žene nemaju značajniju ulogu u društvu, osim da podupiru karijeru svoga muža te nemogućnost postojanja uspješnog braka u kojem žena ima veću zaradu od svoga muža. 
nente koje su zajedno tumačile $61,4 \%$ ukupne varijance instrumenta (koje su gotovo u potpunosti korespondirale dvjema konceptualno pretpostavljenim sadržajnim domenama tradicionalnog seksizma), skala zadovoljava Carminesove i Zellerove (1979) kriterije jednodimenzionalnosti ${ }^{12}$ pa je kao takvu i tretiramo u daljnjima analizama. Pouzdanost skale izražena Cronbachovim koeficijentom bila je vrlo visoka $(\alpha=0,905)$.

\subsubsection{Skala stavova prema feminističkom pokretu (SSFP)}

Skala stavova prema feminističkom pokretu (engl. Attitudes Toward Feminism and the Women's Movement Scale - FWM) u potpunosti je preuzeta od Fassinger (1994). Skala se izvorno sastoji od 10 čestica, a u ovoj studiji je korišteno njih osam, te su čestice procjenjivane na ordinalnoj skali slaganja od pet stupnjeva. ${ }^{13}$ Veći rezultat na skali reprezentira veći stupanj iskazivanja pozitivnih stavova prema feminističkom pokretu. Analiza dimenzionalnosti SSFP-a metodom glavnih komponenata pokazala je da je riječ o jednodimenzionalnoj skali (dobivena je jedna komponenta koja tumači 54,7\% ukupne varijance instrumenta) te da je pouzdanost skale visoka $(\alpha=0,882)$. Dakle, i u naaoj studiji ova skala predstavlja pouzdanu i valjanu mjeru afektivnih stavova prema feminističkom pokretu, kako zaključuje i Fassinger (1994).

\subsection{Statistička obrada podataka}

Statistička obrada podataka provedena je pomoću statističkih programa IBM SPSS Statistics 25 i jamovi 1.2.27. Pojedinačne čestice SSS-a kao i konačna inačica SSS-a analizirane su deskriptivno (određivanjem aritmetičkih sredina, standardnih devijacija, medijana, kvartila, koeficijenta asimetrija i koeficijenta zakrivljenosti). Kako bismo ustanovili postoji li razlika u prosječnom rezultatu na SSS-u između pripadnika različitog spola korišten je t-test za nezavisne uzorke za nehomogene varijance (tzv. Welchov test) i Cohenov d kao pokazatelj jačine efekta. Pearsonovi koeficijenti korelacije određeni su za utvrdivanje direktnih veza između rezultata na SSS-u s rezultatima na SSFP i STS. Od multivarijatnih metoda analize podataka korištene su sljedeće: 1. analiza glavnih komponenata uz GK kriterij za zadržavanje komponenti kojom smo ispitali dimenzionalnost SSS-a (dodatno i paralelna analiza za zadržavanje komponenti u jamovi-u) i oblimin tranformaciju bazične solucije; te 2 . multivarijatna linearna regresijska analiza, kao i hijerarhijska multivarijatna linearna regresija, kojima smo pokušali ustanoviti koji prediktori i u kojoj mjeri tumače varijancu SSS-a te kako izgledaju spolno specifični

12 Prvo, prva ekstrahirana komponenta u bazičnoj soluciji objašnjava veliku proporciju ukupne varijance instrumenta (preko 40\% ukupne varijance instrumenta, odnosno 52,7\%). Drugo, sve čestice imaju relativno visoke saturacije na prvu komponentu (od 0,590 do 0,818). Treće, sve čestice, imaju veće saturacije na prvu komponentu nego na komponente koje slijede. Četvrto, komponente imaju relativno visoku povezanost $(r=0,609)$.

13 Navodimo dva primjera čestica koje tvore SSFP: „Ženski pokreti ostvarili su značajne doprinose u postizanju jednakih prava i političke moći za žene“ (pozitivna čestica) i „Ženski pokreti su u svojim stajalištima previše radikalni i ekstremni” (negativna čestica). 
modeli za tumačenje suvremenog seksizma. Za provjeru pretpostavki za primjerenost provedbe analize glavnih komponenata analizirani su koeficijenti asimetrije pojedinih čestica za konstrukciju skale vodeći se sugestijom Gaskina i Happella (2014:515) da apsolutni iznosi koeficijenata asimetrije varijabli koje ulaze u komponentu faktorsku analizu trebaju biti manji od 1 . Nadalje, proveden je Bartlettov test sfericiteta, koji testira hipotezu da je matrica korelacija jednaka matrici identiteta (analiza je primjerena ako se ova hipoteza odbaci) te je također provjerena Kaiser-Meyer-Olkinova mjera adekvatnosti uzorkovanja (KMO koeficijent), koja služi za provjeru primjerenosti korelacijske matrice za provođenje analize, a za koju je poželjno da bude što veća, a svakako veća od 0,5 (Hair i sur., 2014). Pouzdanost instrumenata procijenjena je analizom interne konzistentnosti na temelju Cronbachovog $\alpha$ koeficijenta. Nunnally i Bernstein (1994) prihvatljivom pouzdanošću smatraju iznose Cronbachovog $\alpha$ većih od 0,7 , ali navode da je uputno težiti koeficijentima iznad 0,8. Kline (1998) navodi sljedeće kriterije pouzdanosti mjernih instrumenata: izvrsne mjerne skale dosežu vrijednosti oko 0,9 , vrlo dobre skale vrijednosti oko 0,8 , a prihvatljive skale vrijednosti oko 0,7 . George i Mallery (2003) pri tumačenju koeficijenta pouzdanosti Cronbachovog a koriste sljede e kriterije: manja od 0,5 je neprihvatljiva pouzdanost; 0,5-0,6 loaa; 0,6-0,7 osrednja; 0,7-0,8 dobra (prihvatljiva); 0,8-0,9 vrlo dobra; te veća od 0,9 izvrsna. Odstupanje oblika distribucije frekvencija rezultata na SSS-u od normalne Gaussove distribucije testirano je Kolmogorov-Smirnovljevim testom. Svi statistički testovi provedeni su na razini rizika $5 \%$.

\section{REZULTATI}

\subsection{Deskriptivna obilježja čestica SSS-a}

Iz Tablice 2 vidljivo je da su čestice koje imaju najveće iznose aritmetičkih sredina, odnosno čestice $s$ kojima se ispitane studentice i studenti najviše slažu, upravo negativne tvrdnje, tj. one koje ne idu u prilog iskazivanju suvremenih seksističkih stavova. To je pokazatelj da, općenito gledano, ispitani studenti i studentice generalno nisu skloni konceptu suvremenog seksizma. Distribucije rezultata na pojedinim česticama koje izražavaju suvremene seksističke sadržaje lijevo su asimetrične, što što je u skladu s nalazima primjerice Glicka i suradnica (2002) da su mlađi i obrazovaniji ispitanici manje skloni iskazivati suvremene seksističke stavove prema ženama.

Apsolutni iznosi koeficijenata asimetrije svih 29 čestica kreću se između 0,116 i 1,492, pri čemu pet čestica ima iznos koeficijenta asimetrije veći od $1,{ }^{15}$ što smatramo dovoljno

14 Usporedba rezultata na česticama SSS-a olakšana je uz pomoć usporedbe aritmetičkih sredina (M), odnosno čestice su sortirane prema iznosu aritmetičkih sredina počevši s onom koja ima najveće prosječno slaganje. Za sve čestice SSS-a ukupni N iznosi 402, a zbroj postotaka iznosi 100\%. Dodatno valja istaknuti kako čestice č05 i č20 iako su uključene u Tablicu 2. na kraju ipak nisu uključene u konačnu verziju SSS-a. 15 Jedna od tih pet nije zadržana u konačnoj inačici skale. 


\begin{tabular}{|c|c|c|c|c|c|c|c|c|c|c|c|c|c|}
\hline \multirow{3}{*}{ 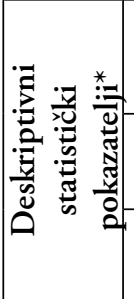 } & $8^{m}$ & $\begin{array}{l}\overrightarrow{0} \\
\overrightarrow{1}\end{array}$ & $\begin{array}{l}\text { Fे } \\
\hat{0}\end{array}$ & \begin{tabular}{l}
$\stackrel{\infty}{+}$ \\
\multirow{1}{i}{}
\end{tabular} & $\begin{array}{c}1 \\
\tilde{\sigma} \\
0 \\
0 \\
1 \\
\end{array}$ & $\begin{array}{l}\infty \\
\infty \\
n \\
i\end{array}$ & $\begin{array}{l}2 \\
\overline{0} \\
0\end{array}$ & 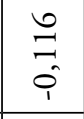 & \begin{tabular}{l}
$\infty$ \\
\multirow{2}{1}{} \\
0 \\
0
\end{tabular} & $\frac{1}{2}$ & 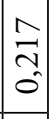 & $\begin{array}{l}2 \\
\hat{2} \\
\hat{0}\end{array}$ & $\frac{0}{n}$ \\
\hline & ค & $\stackrel{8}{\circ}$ & $\stackrel{ }{=}$ & $\stackrel{\infty}{=}$ & $\stackrel{0}{=}$ & $\stackrel{\infty}{\sim}$ & $\stackrel{+}{0}$ & $\stackrel{n}{\approx}$ & $\stackrel{\overbrace{}}{\sim}$ & $\stackrel{\sim}{\sim}$ & $\stackrel{2}{\sim}$ & $\stackrel{\sim}{-}$ & $\stackrel{2}{\pi}$ \\
\hline & $\Sigma$ & $\exists$ & $\begin{array}{l}\stackrel{0}{0} \\
i\end{array}$ & 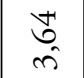 & $\begin{array}{l}n \\
n\end{array}$ & $\hat{n}$ & $\begin{array}{l}0 \\
n \\
n\end{array}$ & $\begin{array}{l}\infty \\
0 \\
\infty\end{array}$ & $\begin{array}{c}\infty \\
\infty \\
N\end{array}$ & $\begin{array}{l}\text { ?ర్ } \\
\text { in }\end{array}$ & $\left|\begin{array}{l}0 \\
0 \\
i\end{array}\right|$ & $\begin{array}{l}\tilde{6} \\
\sqrt{2}\end{array}$ & ָ̊ \\
\hline \multirow{5}{*}{$\begin{array}{l}\pi \\
0 \\
0 \\
0 \\
0 \\
0 \\
0 \\
0 \\
0 \\
0 \\
0 \\
0 \\
0\end{array}$} & 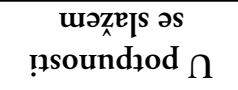 & 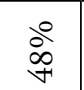 & 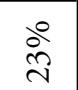 & $\stackrel{\circ}{\stackrel{\circ}{\imath}}$ & ลี & ذి & ஓ̊ & $\stackrel{\stackrel{\circ}{ \pm}}{=}$ & $\stackrel{\circ}{=}$ & $\stackrel{\circ}{\stackrel{0}{+}}$ & $\rho^{0}$ & $\stackrel{\circ}{\beth}$ & ฉ̊ \\
\hline & วs шәz્રિIS & 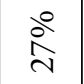 & $\frac{\partial}{\forall}$ & $\begin{array}{l}0 \\
\infty \\
\infty\end{array}$ & $\left|\begin{array}{c}0 \\
\infty \\
\infty \\
n\end{array}\right|$ & 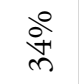 & î̀ & $\begin{array}{l}\stackrel{0}{\infty} \\
\infty \\
\text { N }\end{array}$ & 离 & ה̀ & 客 & $\begin{array}{l}0 \\
\infty \\
-1\end{array}$ & 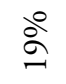 \\
\hline & 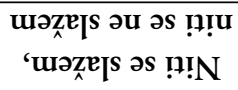 & o̊ & $\frac{\partial}{2}$ & $\stackrel{\circ}{\check{\beth}}$ & $\mid \frac{0}{2}$ & $\grave{\sigma}_{-1}^{0}$ & $\mid \begin{array}{l}0 \\
\stackrel{0}{+} \\
\forall\end{array}$ & 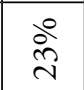 & $\stackrel{\stackrel{\circ}{ \pm}}{\square}$ & 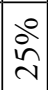 & $\mid \begin{array}{l}0 \\
2 \\
\sim\end{array}$ & ஓे & $\stackrel{\circ}{\stackrel{2}{2}}$ \\
\hline & 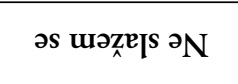 & \&े & ฉे & $\stackrel{\circ}{\circ}$ & ¿̊ & $\stackrel{\circ}{1}$ & 通 & ते & $\begin{array}{l}\text { वे } \\
\text { ले }\end{array}$ & \begin{tabular}{|l}
$\hat{m}^{\circ}$ \\
na
\end{tabular} & \begin{tabular}{|c|} 
\\
0 \\
0 \\
0
\end{tabular} & 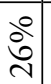 & 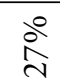 \\
\hline & $\begin{array}{c}\text { uəż्रe[s } \\
\text { əu əs əọdo } \bigcap\end{array}$ & ेे & b̊ & $\stackrel{\circ}{\infty}$ & 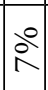 & $\stackrel{\circ}{\circ}$ & $\infty^{0}$ & $\stackrel{\circ}{n}$ & $\stackrel{\circ}{\beth}$ & ᄋ̊రి & ป̀ & $\begin{array}{l}\stackrel{0}{\sim} \\
\stackrel{\sim}{n}\end{array}$ & 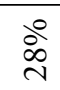 \\
\hline & \multirow[t]{2}{*}{ 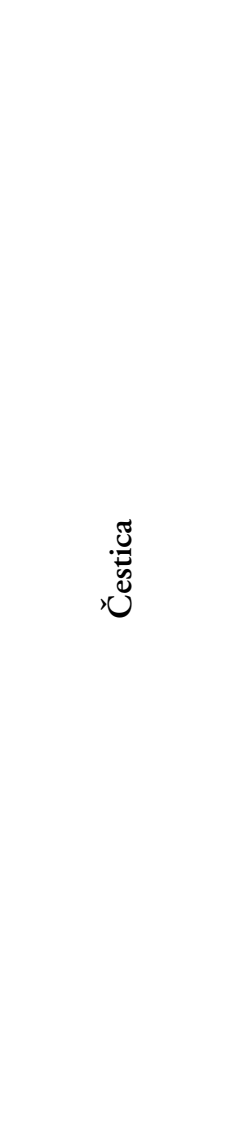 } & 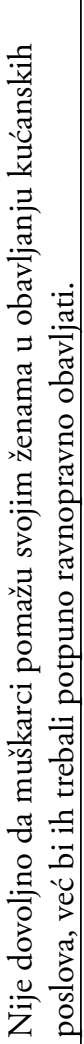 & 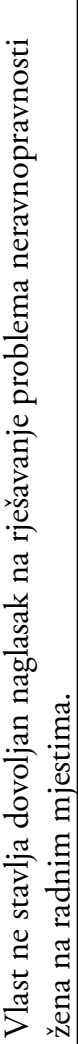 & 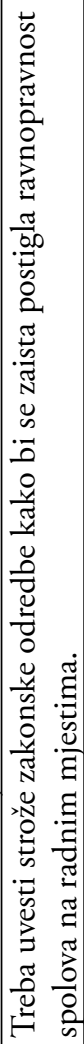 & 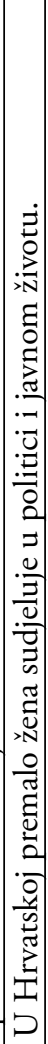 & 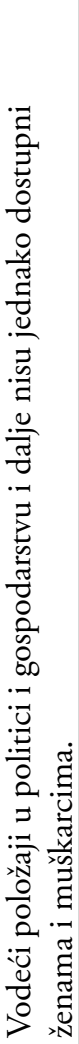 & 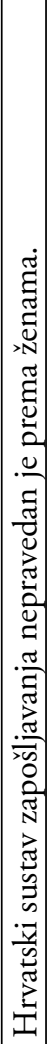 & 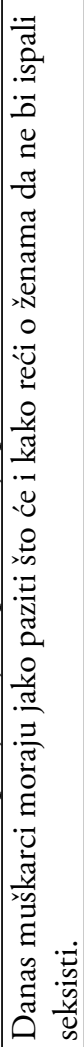 & 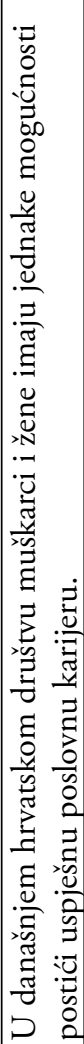 & 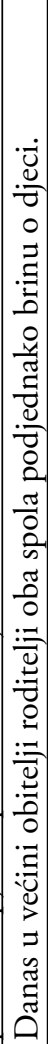 & 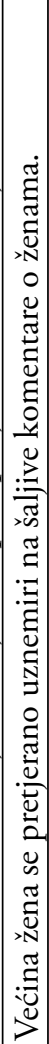 & 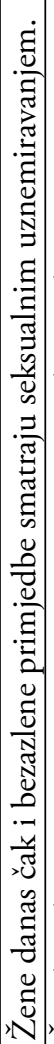 & 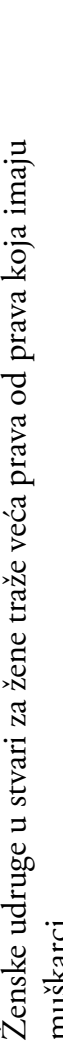 \\
\hline & & ત્ల & $\hat{o}$ & 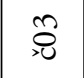 & : & $\stackrel{\nabla}{\Delta}$ & $\frac{\lambda}{\Delta U}$ & 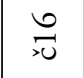 & ¿ & $\tilde{\imath}$ & $\underset{N}{\mathbb{N}}$ & $\frac{m}{\pi 0}$ & $\begin{array}{l}\infty \\
\text { N }\end{array}$ \\
\hline
\end{tabular}




\begin{tabular}{|c|c|c|c|c|c|c|c|c|c|c|c|c|c|c|c|c|}
\hline $\begin{array}{l}\underset{n}{*} \\
\stackrel{\sigma}{*}\end{array}$ & $\mid \begin{array}{c}+1 \\
0 \\
n \\
0 \\
0\end{array}$ & $\begin{array}{l}\infty \\
\stackrel{\infty}{\mathscr{N}} \\
\stackrel{0}{0}\end{array}$ & $\begin{array}{l}\stackrel{0}{\mathscr{n}} \\
\stackrel{\leftrightarrow}{o} \\
0\end{array}$ & 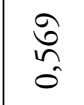 & $\frac{n}{\hat{n}}$ & $\begin{array}{l}n \\
\tilde{n} \\
\tilde{0}\end{array}$ & $\begin{array}{l}\vec{\sigma} \\
0 \\
0\end{array}$ & $\begin{array}{l}0 \\
0 \\
\infty \\
0 \\
0\end{array}$ & $\begin{array}{l}\text { ळे } \\
\infty \\
0\end{array}$ & $\begin{array}{l}\infty \\
\infty \\
\infty \\
0\end{array}$ & $\begin{array}{l}\stackrel{Y}{+} \\
\infty \\
0\end{array}$ & $\begin{array}{l}- \\
\delta \\
\delta \\
\delta\end{array}$ & $\begin{array}{c}0 \\
0 \\
0 \\
-1\end{array}$ & 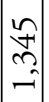 & $\begin{array}{l}\stackrel{+}{\infty} \\
\stackrel{=}{=}\end{array}$ & $\underset{\sim}{\stackrel{\sim}{\sim}}$ \\
\hline 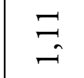 & 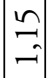 & $\widetilde{\sim}$ & $\stackrel{ }{\cong}$ & $\approx$ & $\stackrel{\leftrightarrows}{\leftrightarrows}$ & 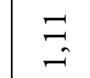 & $\stackrel{\Xi}{\leftrightarrows}$ & $\begin{array}{l}0 \\
\underline{-1} \\
=1\end{array}$ & $\stackrel{m}{\rightarrow}$ & $\stackrel{n}{\Rightarrow}$ & 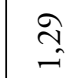 & & $\begin{array}{c}\infty \\
0 \\
0 \\
-1\end{array}$ & $\stackrel{=}{=}$ & $\stackrel{0}{0}$ & $\hat{\sigma}$ \\
\hline กิ & $\vec{n}$ & 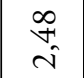 & $\begin{array}{l}\stackrel{n}{*} \\
\stackrel{i}{*}\end{array}$ & $\begin{array}{l}\stackrel{N}{t} \\
\stackrel{\sim}{N}\end{array}$ & $\begin{array}{l}\stackrel{\infty}{n} \\
i\end{array}$ & $\hat{n}$ & $\begin{array}{l}\stackrel{0}{n} \\
\text { in }\end{array}$ & 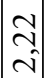 & $\begin{array}{l}\text { î } \\
\text { î }\end{array}$ & $\begin{array}{l}\text { ì } \\
\text { vi }\end{array}$ & $\frac{\infty}{a}$ & $\frac{n}{3}$ & 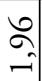 & $\left|\begin{array}{l}\infty \\
\infty \\
-1\end{array}\right|$ & $\stackrel{n}{\infty}$ & 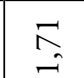 \\
\hline bे & $\begin{array}{l}\partial^{0} \\
\text { n. }\end{array}$ & $\stackrel{\circ}{R}$ & $\dot{b}^{0}$ & $\stackrel{0}{0}^{\circ}$ & $\stackrel{R}{R}^{0}$ & in & iे & $i^{0}$ & ஓ̊ & ᄋ̊o & $\stackrel{\circ}{\infty}$ & ì & ڤे & î & ஓे & 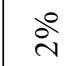 \\
\hline $\begin{array}{l}\stackrel{0}{ } \\
\text { ले }\end{array}$ & 客 & $\stackrel{\stackrel{\circ}{n}}{\stackrel{n}{n}}$ & 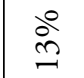 & $\stackrel{\text { ڤ̊ }}{\sim}$ & $\stackrel{\circ}{\circ}$ & ฉ̊ & $\stackrel{\circ}{\beth}$ & $\stackrel{2}{R}^{\circ}$ & $\stackrel{\stackrel{̊}{\beth}}{ }$ & $\stackrel{R}{R}$ & 今̊ & 号 & $\stackrel{\circ}{\infty}$ & in & ेे & ஓे \\
\hline $\begin{array}{l}\stackrel{0}{ } \\
\text { ఎे }\end{array}$ & $\mid \begin{array}{l}0 \\
\infty \\
\text { సे }\end{array}$ & 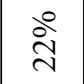 & ذ্ণ & $\frac{\partial^{0}}{\vec{v}}$ & 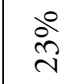 & 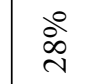 & 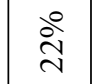 & $\stackrel{\circ}{\text { ते }}$ & $\stackrel{\circ}{\beth}$ & $\stackrel{\circ}{\infty}$ & $\stackrel{\circ}{\stackrel{0}{n}}$ & i̊ & $\begin{array}{l}0 \\
\stackrel{+}{ \pm}\end{array}$ & 욕 & $\stackrel{\delta}{0}^{\circ}$ & $\stackrel{\partial^{0}}{\beth}$ \\
\hline$\stackrel{\stackrel{\circ}{+}}{\stackrel{m}{m}}$ & 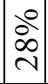 & $\frac{\partial^{0}}{m}$ & o̊ & 仓े & $\begin{array}{l}\stackrel{0}{ } \\
\infty \\
\text { m }\end{array}$ & $\stackrel{\text { ஸे }}{\text { nิ }}$ & $\begin{array}{l}\text { oे } \\
\text { di }\end{array}$ & $\begin{array}{l}\stackrel{0}{ }^{2} \\
\text { m. }\end{array}$ & $\stackrel{\stackrel{0}{~}}{\wedge}$ & $\begin{array}{l}\stackrel{0}{\circ} \\
\infty \\
\text { mo }\end{array}$ & $\begin{array}{l}\stackrel{\circ}{\imath} \\
\stackrel{\imath}{v}\end{array}$ & 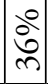 & $\begin{array}{l}\stackrel{0}{2} \\
\text { กै }\end{array}$ & $\stackrel{\circ}{\stackrel{0}{2}}$ & ڤે & $\stackrel{\stackrel{े}{n}}{\text { ñ }}$ \\
\hline$\stackrel{\stackrel{\circ}{二}}{ }$ & ڤે) & 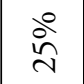 & $\begin{array}{l}\stackrel{\circ}{\sim} \\
\stackrel{\sim}{\sim}\end{array}$ & $\begin{array}{l}\stackrel{0}{\circ} \\
\stackrel{\sim}{0}\end{array}$ & 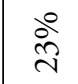 & i̊ㅇ & $\begin{array}{l}\stackrel{\circ}{\sim} \\
\stackrel{n}{v}\end{array}$ & 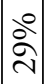 & $\frac{\partial^{\circ}}{\forall}$ & $\frac{\partial^{0}}{m}$ & 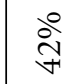 & $\mid \begin{array}{c}0 \\
\stackrel{+}{+} \\
m\end{array}$ & 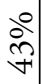 & $\frac{0}{n}$ & $\dot{b}_{+\rightarrow}^{\circ}$ & $\stackrel{\stackrel{\circ}{N}}{\text { กิ }}$ \\
\hline 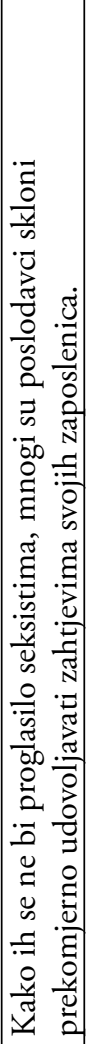 & 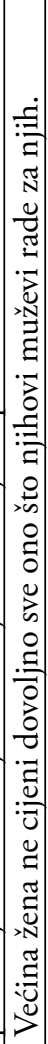 & 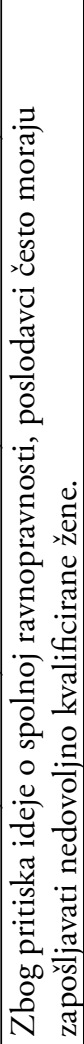 & 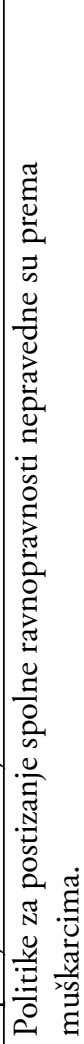 & 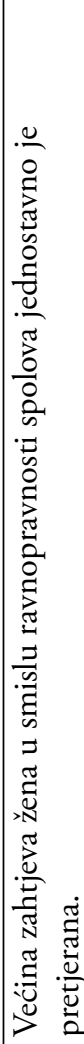 & 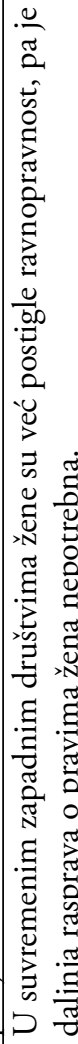 & 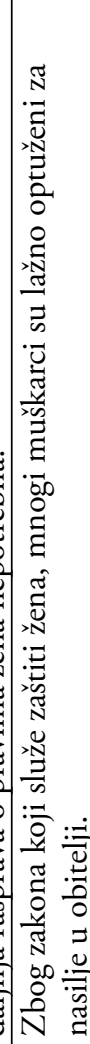 & 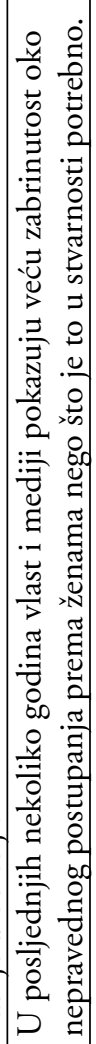 & 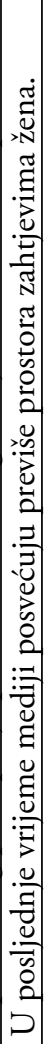 & 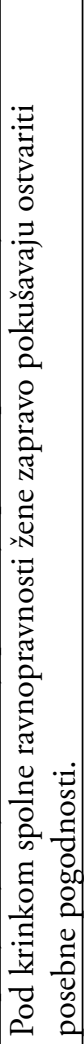 & 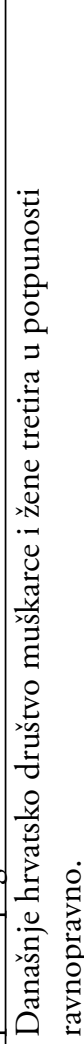 & 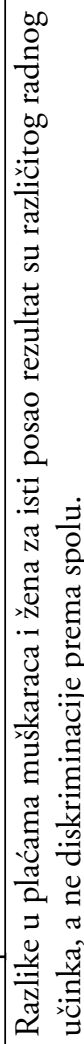 & 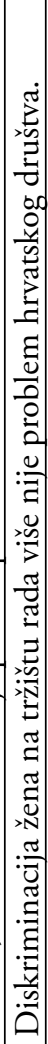 & 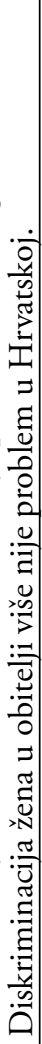 & 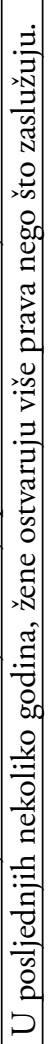 & 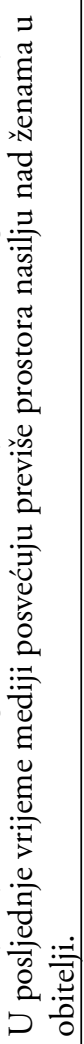 & 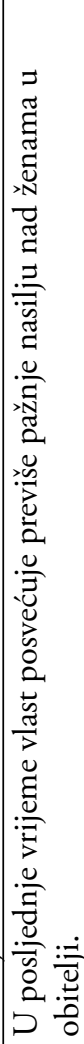 \\
\hline 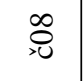 & $\widehat{N}$ & స్ & $\stackrel{\widetilde{U}}{\overparen{U}}$ & ชิ & $\underset{\text { ๖̦ }}{+\infty}$ & $\frac{\infty}{\bar{v}}$ & $\frac{n}{\pi v}$ & $\stackrel{\vartheta}{\overline{0}}$ & $\frac{N}{x}$ & $\tilde{N}$ & $\overrightarrow{\mathrm{N}}$ & $\underset{>0}{0}$ & & ○े & 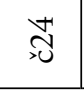 & $\overline{\bar{v}}$ \\
\hline
\end{tabular}


malim odstupanjima od sugestija koje daju Gaskin i Happell (2014) da bismo cijeli set čestica mogli podvrgnuti analizama koje prikazujemo u nastavku.

\subsection{Dimenzionalnost SSS-a}

$\mathrm{Za}$ analizu dimenzionalnosti instrumenta koji mjeri suvremeni seksizam, korištena je analiza glavnih komponenata. Bartlettov test sfericiteta bio je statistički značajan $(\mathrm{p}<0,001)$, a KMO iznosa 0,971 , pa smo zaključili da su podaci primjereni za provjeru dimenzionalnosti analizom glavnih komponenata. Analiza na svim inicijalno uključenim česticama (njih 29) pokazala je da bazična solucija rezultira s četiri komponente zadržane prema GK kriteriju koji zajedno tumače $65,2 \%$ ukupne varijance instrumenta. ${ }^{16}$ Potom smo pristupili tzv. „čišćenju“ faktorske solucije, tj. isključivanju pojedinih čestica iz završne inačice skale, pri čemu nam je primarni cilj bio povećati pouzdanost instrumenta kako bi u isto vrijeme dobili pouzdan te sadržajno zadovoljavajući, ali i jednostavniji, odnosno kraći instrument.

Inicijalno, Cronbachov $\alpha$ koeficijent za svih 29 čestica iznosio je 0,964 . Uočili smo kako se Cronbachov a koeficijent može povećati isključivanjem negativne čestice „Nije dovoljno da muškarci pomažu svojim ženama u obavljanju kućanskih poslova, već bi ih trebali potpuno ravnopravno obavljati “. Postotak ukupne protumačene varijance instrumenta se $s$ inicijalnih $65,2 \%$ smanjio na $63,1 \%$, ali se zato broj zadržanih komponenata smanjio s četiri na tri komponente, odnosno isključivanjem ove čestice „nestala je“ komponenta specificiteta koju je činila isključivo navedena čestica, a pouzdanost skale neznatno se povećala na $\alpha=0,965$.

Daljnjom analizom interne konzistentnosti utvrdili smo kako se Cronbachov $\alpha$ još može neznatno povećati na 0,966 isključivanjem čestice „Danas u véini obitelji roditelji oba spola podjednako brinu o djeci“. Isključivanjem ove čestice broj zadržanih komponenata ostao je nepromijenjen (tri komponente), ali se postotak ukupne protumačene varijance instrumenta sa $63,1 \%$ povećao na $64,6 \%$.

Analiza pouzdanosti pokazala je da se Cronbachov a daljnjim isključivanjem čestica ne može dodatno povećati. Nakon isključivanja dviju navedenih čestica, prema kriteriju dobivanja veće pouzdanosti instrumenta u bazičnoj su soluciji zadržane tri komponente koje su zajedno tumačile $64,6 \%$ ukupne varijance instrumenta. Prva komponenta u bazičnoj soluciji tumači $53,8 \%$, druga $6,8 \%$, a treća $4,1 \%$ ukupne varijance instrumenta. Tablica 3 prikazuje saturacije svih zadržanih čestica na tri zadržane komponente, pri oblimin transformaciji, uz GK kriterij za zaustavljanje ekstrakcije komponenti.

Prva je komponenta okupila ukupno 14 čestica koje dolaze iz sve četiri sadržajne domene. Samo jedna čestica dolazi iz domene nijekanje postojanja daljnje diskriminacije žena, šest čestica dolaze iz domene antagonizam spram zahtjeva žena, četiri čestice iz domene ogorčenje zbog posebnih pogodnosti koje žene dobivaju samo zbog toga što su žene te tri če-

16 Prva komponenta u inicijalnoj bazičnoj soluciji (29 čestica) tumačila je 51\%, druga 6,5\%, treća 4,1\%, a četvrta 3,5\% ukupne varijance instrumenta. 
stice dolaze iz domene zamjeranje ženama zbog "preosjetlivosti“ na seksizam i seksualno uznemiravanje. Ova komponenta okupila je iznimno velik broj čestica vrlo različitih sadržaja te istovremeno obuhvaća i privatnu i javnu sferu djelovanja žena, pa ga zbog toga nije lako nasloviti i interpretirati.

\section{Tablica 3. Konačna matrica strukture uz oblimin transformaciju (27 zadržanih čestica)}

\begin{tabular}{|c|c|c|c|}
\hline \multirow[t]{2}{*}{ Čestica } & \multicolumn{3}{|c|}{$\begin{array}{l}\text { Ekstrahirane } \\
\text { komponente }\end{array}$} \\
\hline & 1 & 2 & 3 \\
\hline $\begin{array}{l}\text { č13: Žene danas čak i bezazlene primjedbe smatraju seksualnim } \\
\text { uznemiravanjem. }\end{array}$ & ,827 &,- 525 & ,318 \\
\hline $\begin{array}{l}\text { č12: Pod krinkom spolne ravnopravnosti žene zapravo pokušavaju } \\
\text { ostvariti posebne pogodnosti. }\end{array}$ &, 815 &,- 635 & ,393 \\
\hline $\begin{array}{l}\text { č22: Većina žena se pretjerano uznemiri na šaljive komentare o } \\
\text { ženama. }\end{array}$ & ,809 &,- 406 & ,230 \\
\hline $\begin{array}{l}\text { č09: U posljednjih nekoliko godina, žene ostvaruju više prava nego } \\
\text { što zaslužuju. }\end{array}$ &, 804 &,- 525 & ,484 \\
\hline $\begin{array}{l}\text { č28: Ženske udruge u stvari za žene traže veća prava od prava koja } \\
\text { imaju muškarci. }\end{array}$ &, 803 &,- 733 & ,425 \\
\hline $\begin{array}{l}\text { č19: U posljednje vrijeme mediji posvećuju previše prostora } \\
\text { zahtjevima žena. }\end{array}$ & 799 &,- 596 & ,539 \\
\hline $\begin{array}{l}\text { č26: Zbog pritiska ideje o spolnoj ravnopravnosti, poslodavci često } \\
\text { moraju zapošljavati nedovoljno kvalificirane žene. }\end{array}$ & ,797 &,- 575 & ,264 \\
\hline $\begin{array}{l}\text { č16: Danas muškarci moraju jako paziti što će i kako reći o ženama } \\
\text { da ne bi ispali seksisti. }\end{array}$ & ,795 &,- 467 & ,325 \\
\hline $\begin{array}{l}\text { č23: Politike za postizanje spolne ravnopravnosti nepravedne su } \\
\text { prema muškarcima. }\end{array}$ & ,790 &,- 627 & ,407 \\
\hline $\begin{array}{l}\text { č02: Većina zahtjeva žena u smislu ravnopravnosti spolova } \\
\text { jednostavno je pretjerana. }\end{array}$ & ,757 &,- 692 & ,458 \\
\hline $\begin{array}{l}\text { č15: U posljednjih nekoliko godina vlast i mediji pokazuju veću } \\
\text { zabrinutost oko nepravednog postupanja prema ženama nego } \\
\text { što je to u stvarnosti potrebno. }\end{array}$ & ,733 &,- 614 & ,626 \\
\hline $\begin{array}{l}\text { č08: Kako ih se ne bi proglasilo seksistima, mnogi su poslodavci } \\
\text { skloni prekomjerno udovoljavati zahtjevima svojih zaposlenica. }\end{array}$ &, 732 &,- 428 & ,305 \\
\hline $\begin{array}{l}\text { č27: Većina žena ne cijeni dovoljno sve ono što njihovi muževi rade } \\
\text { za njih. }\end{array}$ & ,692 &,- 424 & 263 \\
\hline $\begin{array}{l}\text { č18: Zbog zakona koji služe zaštiti žena, mnogi muškarci su lažno } \\
\text { optuženi za nasilje u obitelji. }\end{array}$ & ,670 &,- 313 & ,429 \\
\hline $\begin{array}{l}\text { č07: Vlast ne stavlja dovoljan naglasak na rješavanje problema } \\
\text { neravnopravnosti žena na radnim mjestima. }\end{array}$ &,- 585 & ,853 &,- 263 \\
\hline $\begin{array}{l}\text { č14: Vodeći položaji u politici i gospodarstvu i dalje nisu jednako } \\
\text { dostupni ženama i muškarcima. }\end{array}$ &,- 469 & ,793 &,- 259 \\
\hline
\end{tabular}




\begin{tabular}{|l|c|c|c|}
\hline $\begin{array}{c}\text { č10: Diskriminacija žena na tržištu rada više nije problem hrvatskog } \\
\text { društva. }\end{array}$ &, 666 &,- 788 &, 596 \\
\hline $\begin{array}{c}\text { č03: Treba uvesti strože zakonske odredbe kako bi se zaista postigla } \\
\text { ravnopravnost spolova na radnim mjestima. }\end{array}$ &,- 435 &, 746 &,- 151 \\
\hline č06: U Hrvatskoj premalo žena sudjeluje u politici i javnom životu. &,- 523 &, 742 &,- 059 \\
\hline $\begin{array}{l}\text { č01: U današnjem hrvatskom društvu muškarci i žene imaju } \\
\text { jednake mogućnosti postići uspješnu poslovnu karijeru. }\end{array}$ &, 421 &,- 739 &, 485 \\
\hline č17: Hrvatski sustav zapošljavanja nepravedan je prema ženama. &,- 444 &, 721 &,- 189 \\
\hline č29: Diskriminacija žena u obitelji više nije problem u Hrvatskoj. &, 636 &,- 719 &, 608 \\
\hline $\begin{array}{l}\text { č25: Današnje hrvatsko društvo muškarce i žene tretira u potpunosti } \\
\text { ravnopravno. }\end{array}$ &, 472 &,- 704 &, 639 \\
\hline $\begin{array}{c}\text { č21: Razlike u plaćama muškaraca i žena za isti posao rezultat su } \\
\text { različitog radnog učinka, a ne diskriminacije prema spolu. }\end{array}$ &, 675 &,- 695 &, 488 \\
\hline $\begin{array}{l}\text { č04: U suvremenim zapadnim društvima žene su već postigle } \\
\text { ravnopravnost, pa je daljnja rasprava o pravima žena } \\
\text { nepotrebna. }\end{array}$ &, 599 &,- 624 &, 589 \\
\hline $\begin{array}{c}\text { č11: U posljednje vrijeme vlast posvećuje previše pažnje nasilju nad } \\
\text { ženama u obitelji. }\end{array}$ &, 573 &,- 369 &, 749 \\
\hline $\begin{array}{l}\text { č24: U posljednje vrijeme mediji posvećuju previše prostora nasilju } \\
\text { nad ženama u obitelji. }\end{array}$ &, 675 &,- 407 &, 733 \\
\hline \begin{tabular}{l} 
Svojstvene vrijednosti komponenata \\
\hline
\end{tabular} & 12,47 & 10,61 & 5,56 \\
\hline
\end{tabular}

Najveći dio čestica koje čine ovu komponentu odnosi se na nezadovoljstvo, antagonizam i ogorčenje zbog posebnih zahtjeva, prava i pogodnosti koje žene traže, i naposljetku možda i dobivaju samo zbog toga što su žene. Stoga smatramo kako je prvu zadržanu komponentu opravdano radno nazvati Antagonizam spram posebnih zahtjeva, prava i pogodnosti koje žene traže i dobivaju samo zbog toga što su žene, čime zapravo u konceptualnom smislu naglasak ove komponente pripisujemo kombinaciji druge i treće konceptualno osmišljene sadržajne domene suvremenog seksizma.

Druga je komponenta okupila ukupno 11 čestica od kojih devet čestica dolazi iz domene nijekanje postojanja daljnje diskriminacije žena, a preostale dvije čestice dolaze iz domene ogorčenje zbog posebnih pogodnosti koje žene dobivaju samo zbog toga što su žene. Unatoč tome što dvije čestice ne dolaze iz sadržajne domene koja se odnosi na nijekanje postojanja daljnje diskriminacije žena, i dalje se svojim sadržajem dotiču teme nijekanja problema diskriminacije i neravnopravnosti žena. Stoga smatramo kako se ova komponenta može nazvati Nijekanje daljnje diskriminacije i neravnopravnosti žena. Osim toga, valja primijetiti nekoliko zanimljivosti vezanih uz ovu komponentu. Prvo, ova je komponenta okupila svih pet čestica koje su formulirane u negativnom smjeru, odnosno ne idu u prilog iskazivanju suvremenih stavova. Drugo, najveći dio čestica se odnosi na različite odrednice suvremenog seksizma na radnim mjestima i u javnoj političko-gospodarskoj sferi, a tek manji broj čestica odnosi se na izostanak diskriminacije 
i neravnopravnosti žena u društvu općenito, dok se samo jedna čestica dotiče privatne sfere, točnije diskriminacije žena u obitelji.

Treću komponentu u najvećoj mjeri saturiraju samo dvije čestice koje obje dolaze iz sadržajne domene ogorčenje zbog posebnih pogodnosti koje žene dobivaju samo zbog toga što su žene te se obje odnose na preveliko posvećivanje pozornosti i pažnje nasilju nad ženama u obitelji. Unatoč tome što ovu komponentu čine isključivo dvije čestice, smatramo kako ju je potrebno zadržati u konstrukciji SSS-a iz sadržajnih razloga, odnosno smatramo kako je važno da ova skala zahvaća i probleme koji su vezani uz neprepoznavanje i nijekanje društvene relevantnosti problema nasilja nad ženama u obitelji. Shodno tome ovaj ćemo faktor nazvati Nijekanje relevantnosti problema nasilja nad ženama u obitelji. Komponente dobivene oblimin transformacijom bazične solucije međusobno su povezani. Najjača je povezanost, relativno visokog iznosa za oblimin komponente ( $r=-$ 0,590 ), između prve i druge komponente, zatim ona između prve i treće komponente $(\mathrm{r}=0,418)$, dok je povezanost druge i treće komponente umjerena $(\mathrm{r}=-0,329) \cdot{ }^{17}$

Kako bismo provjerili robusnost dobivenih nalaza, učinjena je i dodatna analiza dimenzionalnosti primjenom paralelne analize za zadržavanje komponenti. Dobivena je faktorska solucija s dvije zadržane komponente u kojoj su sve čestice imale jednak raspored pripadajućim komponentama kao i kod primjene GK kriterija, s iznimkom upravo dviju čestica o nasilju nad ženama. One su primjenom GK kriterija formirale odvojenu komponentu, dok su se primjenom paralelne analize priklonile prvoj zadržanoj komponenti.

Naša prosudba dimenzionalnosti konstruirane skale za mjerenje suvremenog seksizma oslanjala se prvenstveno na već ranije navedene Carminesove i Zellerove (1979) kriterije jednodimenzionalnosti koji se odnose na matricu bazične solucije. Ova skala zadovoljava sva četiri Carminesova i Zellerova (1979) kriterija jednodimenzionalnosti. Za početak, prva ekstrahirana komponenta objašnjava veliku proporciju varijance čestica $(53,8 \%)$. Drugo, sljedeće komponente, uz njihovo postupno smanjivanje, objašnjavaju približno jednake proporcije preostale varijance $(6,8 \%, 4,1 \%)$. Treće, sve čestice imaju relativno visoke saturacije na prvu komponentu (od 0,600 do 0,863). Četvrto, sve čestice u bazičnoj soluciji imaju veće saturacije na prvoj komponenti nego na komponentama koje slijede. Napominjemo još kako su pozamašne korelacije koje nisu uobičajene u oblimin transformacijama dodatni pokazatelj koji govori u prilog jednodimenzionalnosti SSS-a. Također, važno je istaknuti još jedan važan kriterij, a to je da su sve zadržane komponente interpretabilne, što smo i pokazali u prethodnim odlomcima. Kako bismo dodatno potvrdili jednodimenzionalnost skale od interesa analizom faktorskih bodova spremljenih kao nove varijable, proveli smo i analizu glavnih komponenata drugog reda kojom smo dobili jednu, generalnu komponentu koja tumači 63,4\% ukupne varijance.

17 Negativni iznosi koeficijenata korelacije rezultat su toga što je pri oblimin transformaciji druga ekstrahirana komponenta prešla u negativne vrijednosti, no to interpretabilno ne mijenja njezin sadržaj. Iz tog razloga negativne korelacije druge komponente s prvom i trećom komponentom ne znače negativne konceptualne veze između tri imenovane latentne dimenzije suvremenog seksizma. 


\subsection{Deskriptivna obilježja SSS-a}

U ovoj studiji na uzorku studenata i studentica prosječni je rezultat na SSS-u bio ispod sredine teorijskog raspona rezultata $(M=64,17 ; S D=23,03)$ koja iznosi 81 . Teorijski raspon varijacija skale (od najmanjeg rezultata iznosa 27 do najvišeg iznosa 135) odgovara i empirijskom rasponu. Medijan iznosi 59,5 a 50\% središnjih rezultata nalazi se u intervalu od $Q_{1}=46$ do $Q_{3}=78$. Distribucija frekvencija rezultata na SSS-u je unimodalna i zvonolika (Slika 2), ali statistički značajno odstupa od normalne $(\mathrm{D}(402)=1,780$; $\mathrm{p}=0,004)$, s koeficijentom asimetrije iznosa 0,701 i koeficijentom zakrivljenosti iznosa $-0,056$.

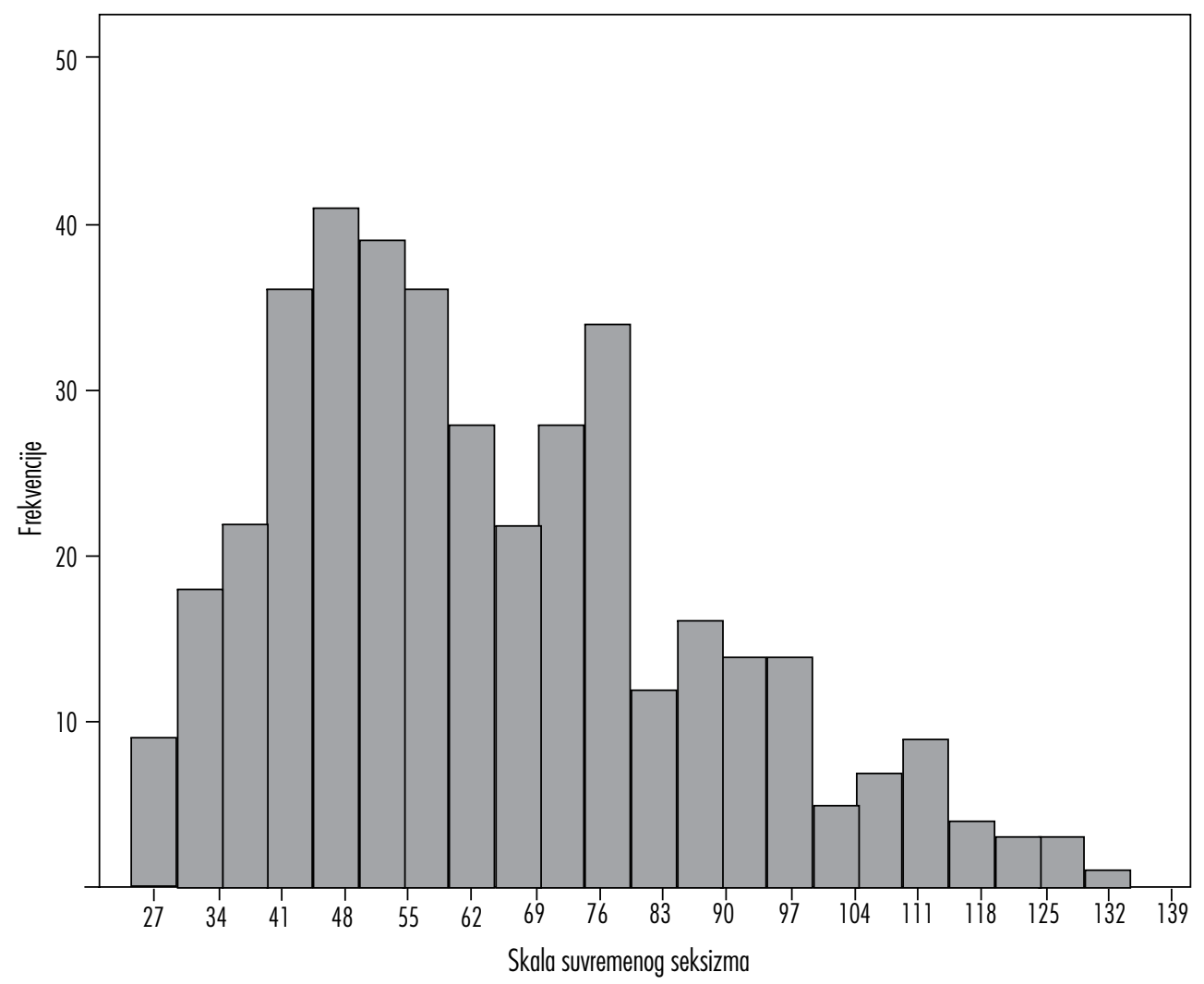

Slika 2. Distribucija frekvencija rezultata na SSS-u (histogram frekvencija)

\subsection{Pouzdanost SSS- $a$}

Pouzdanost SSS-a procijenjena je uvrštavanjem svih 27 zadržanih čestica u analizu interne konzistentnosti te je dobiven Cronbachov $\alpha$ iznosa 0,966. Uzimajui u obzir ranije iznesene kriterije pouzdanosti mjernog instrumenta (Nunnally i Bernstein, 1994; Kline, 1998; George i Mallery, 2003), pouzdanost SSS-a možemo smatrati izvrsnom. Dodatno je provjerena pouzdanost dviju subskala prema dobivenim sadržajnim komponentama. Za 
prvu subskalu koju smo nazvali Antagonizam spram posebnih zahtjeva, prava i pogodnosti koje žene traže i dobivaju samo zbog toga što su žene s 14 čestica dobiven je Cronbachov $\alpha$ iznosa 0,952 , a kad smo im pridodali joa i dvije čestice o nasilju nad ženama (prema rezultatima paralelne analize), subskala sa 16 čestica imala je Cronbachov $\alpha$ iznosa 0,955. Za drugu subskalu Nijekanje daljnje diskriminacije i neravnopravnosti žena pouzdanost $s$ 11 čestica iznosila je $\alpha=0,928$.

\subsection{Valjanost SSS- $a$}

\subsubsection{Sadržajna valjanost SSS-a}

Korištenje obuhvatne konceptualizacije, koja se temelji na četiri sadržajne domene koje zahvaćaju ključne teme za mjerenje različitih tipova suvremenog seksizma, točnije modernog seksizma (Swim i sur., 1995), neoseksizma (Tougas i sur., 1995) te neprijateljskog (hostilnog) seksizma (Glick i Fiske, 1996), bio je nužan preduvjet za konstrukciju sadržajno valjane skale. Prve tri sadržajne domene iz kojih proizlazi većina indikatora, a shodno tome i većina čestica koje smo mjerili, temeljne su sadržajne domene već postojećih skala suvremenih tipova seksizma, odnosno Skale modernog seksizma (Swim i sur., 1995) i Skale neoseksizma (Tougas i sur., 1995), čime smatramo kako je pokriven velik dio relevantnog sadržaja predmeta mjerenja. Dok je dio čestica nastao prilagodbom već postojećih čestica koje su korištene u ranijim istraživanjima suvremenog seksizma, dio je osmišljen od strane autora ovog rada kako bismo pokrili sadržaje koji su prema našem mišljenju nedostajali u postojećim skalama. To se primarno odnosilo na pronalaženje indikatora i za privatnu i za javnu sferu unutar svake sadržajne domene, ovisno o njihovoj primjenjivosti na pojedine sadržaje. Osim toga, valja istaknuti i dodatni istraživački doprinos mjerenju fenomena suvremenog seksizma, a to je osmišljavanje posljednje, četvrte sadržajne domene koja se odnosi na zamjeranje ženama zbog "preosjetlivosti“ "na seksizam i seksualno uznemiravanje. Čestice ove domene zahvaćaju dodatni set suvremenih seksističkih stavova koji do sada nije bio mjeren. Nadalje, valja istaknuti kako smo se za svaku sadržajnu domenu dotaknuli kako javne tako i privatne sfere djelovanja žena, što je dodatna novost u mjerenju suvremenih seksističkih stavova. $S$ druge strane, valja spomenuti kako su prilikom analize dimenzionalnosti i pouzdanosti novokonstruirane skale dvije čestice isključene iz skale, a obje su se odnosile na privatnu, obiteljsku sferu djelovanja žena u domeni nijekanja postojanja daljnje diskriminacije žena. Isključivanjem ovih dviju čestica izgubili smo sadržaje vezane uz raspodjelu kućanskih poslova te raspodjelu poslova oko odgoja i brige o djeci.

Naknadnim promišljanjima autori su došli do novih uvida u potencijalne razloge i implikacije isključivanja ovih čestica iz skale. Naime, moguće je da u pozadini isključivanja čestice „Danas u većini obitelji roditelji oba spola podjednako brinu o djeci“ stoji fenomen modernog očinstva koji je u posljednje vrijeme aktualan i u Hrvatskoj. Iako je ova čestica formulirana u prilog suvremenim seksističkim shvaćanjima koja precjenjuju doprinos muškaraca u obavljanju skrbi za djecu, smatramo da ovu česticu ipak nije bilo primjereno koristiti u takvom obliku. Naime, čestica je formulirana na način da zvuči 
kao opis stanja, a ne izražavanje stava o tome stanju. Primjerice, čak bi se i studenti/ce koji/e se strogo protive konceptu suvremenog seksizma mogli/e složiti s ovom tvrdnjom, uviđajući kako u današnje vrijeme muškarci ipak više sudjeluju u odgoju svoje djece nego što su to činili muškarci prijašnjih generacija. Dok je raspodjela kućanskih poslova ostala i dalje neravnopravno raspodijeljena, u području odgoja i brige o djeci uočavaju se veći pomaci ka rodno integriranim poslovima. To potvrđuju i nalazi istraživanja Topolčića (2001) prema kojima muškarci igru s djetetom ili djecom ne doživljavaju kao posao i ne pada im teško, kao što je to slučaj s obavljanjem kućanskih poslova, ali i ostala istraživanja raspodjele kućanskih obaveza i obiteljskih poslova u Hrvatskoj (Tomić-Koludrović i Kunac, 2000; Čulig i sur. 2007; Klasnić, 2017). Ovdje ipak valja naglasiti da su muškarci aktivniji u onim poslovima i zadacima koji podrazumijevaju fizički izlazak iz prostora privatne sfere, kao što su vođenje djeteta u šetnju te u vrtić ili školu, dok su poslovi koji zahtijevaju ostanak u prostoru doma i privatne sfere (poput hranjenja, oblačenja, učenja i sl.) i dalje aktivnosti koje u velikoj većini obavljaju žene (Klasnić, 2017). Druga isključena čestica glasila je „Nije dovoljno da muškarci pomažu svojim ženama u obavljanju kućanskih poslova, već bi ih trebali potpuno ravnopravno obavljati“. Ova je čestica prvotno uključena kao indikator suvremenog seksizma unutar domene „Nijekanje postojanja daljnje diskriminacije žena“ u privatnoj sferi s idejom da je koncept „pomaganja“ muškaraca u kućanskim poslovima moderan, ali i dalje u svojoj srži patrijarhalan koncept koji zadržava pretpostavku rodne neravnopravnosti kroz impliciranje i dalje zastupljene stroge rodne raspodjele kućanskih poslova. Više je mogućih razloga koji su doveli do nužnosti njezina isključenja iz konačne skale. Kao prvo, čini nam se da je sama formulacija ove čestice vjerojatno ispitanicima bila suviše složena. Također, kao što se može vidjeti, čestica je negativno formulirana, odnosno viši stupanj slaganja s njom konceptualno označava niži stupanj suvremenog seksizma, što također može dovesti do niže korelacije s konceptualno bliskim sadržajima. Ipak, s obzirom na to da je ova čestica činila zasebnu komponentu, tj. da nije bila visoko korelirana s ostalim česticama, zaključujemo kako je koncept pomaganja muškaraca u kućanskim poslovima ipak složeniji fenomen kojeg nije moguće mjeriti isključivo jednom česticom, te je moguće da ga se konceptualno ipak ne može uklopiti unutar koncepta suvremenog seksizma, već ga je potrebno razrađivati kao zaseban predmet mjerenja.

$\mathrm{Na}$ temelju svega navedenog smatramo kako smo obuhvatnom konceptualno-operacionalnom razradom predmeta mjerenja suvremenog seksizma konstruirali sadržajno valjanu SSS.

\subsubsection{Kriterijska valjanost SSS-a}

Kriterijsku valjanost SSS-a procjenjujemo na temelju razlike u rezultatima prema spolu, odnosno na temelju valjanosti poznatih grupa (Spector, 1992). Uz teorijski raspon varijacija od 27 do 135 (sredina teorijskog raspona varijacija $=81$ ), prosjek muškaraca na SSS-u u našem uzorku iznosi 87,3 (SD=22,15), dok prosjek žena iznosi 56,1 $(\mathrm{SD}=17,1)$. Provjera statističke značajnosti razlike u prosjecima prema spolu rezultirala je statistički značajnim $t$-omjerom $(t=13,06 ; \mathrm{df}=148 ; \mathrm{p}<0,001$, Cohenov $\mathrm{d}=1,58)$. 


\subsubsection{Konstruktna valjanost SSS-a}

Konstruktnu valjanost provjerili smo na dva načina: provjerom dimenzionalnosti SSS-a (poglavlje 6.2.) te testiranjem multivarijatnih veza SSS-a sa STS-om i SSFP-om (konvergentna valjanost).

Konvergentna valjanost provjerena je testiranjem multivarijatnih veza linearnim regresijskim analizama na objedinjenom uzorku (hijerarhijska analiza) radi dobivanja uvida u promjenu veza između tradicionalnog seksizma i stavova o feminističkom pokretu sa suvremenim seksizmom uz kontrolu spola, te zasebno na poduzorcima prema spolu radi dobivanja uvida u spolno specifične modele za tumačenje suvremenog seksizma.

Hijerarhijsku multivarijatnu linearnu regresijsku analizu proveli smo u dva koraka, tako da smo u prvom koraku kao potencijalne prediktore uključili STS i SSFP, dok smo u drugom koraku tim dvjema skalama kao prediktor nadodali i spol ispitanika. U prvom koraku oba su prediktora bila statistički značajna te su zajedno objašnjavali $67,7 \%$ ukupne varijance kriterijske varijable SSS-a. Iz Tablice 4 možemo vidjeti kako je SSFP najjači prediktor rezultata na SSS-u, a zatim slijedi STS. U drugom koraku hijerarhijske analize osim dvije navedene skale kao prediktor suvremenih seksističkih stavova dodali smo i spol. U ovom modelu sva su tri uključena prediktora bila statistički značajna, a $\mathrm{R}^{2}$ se povećao na 0,720 . Dakle, tri u model uključena prediktora zajedno su objasnili $72,2 \%$ ukupne varijance kriterija (povećanje od preko $4 \%$ ukupne varijance instrumenta u odnosu na prvi korak). I u ovom koraku povezanost SSS-a bila je najjača sa SSFP-om i to negativna $(\beta=-0,553 ; p<0,001)$, dok je povezanost sa STS-om bila pozitivna $(\beta=0,229$; $\mathrm{p}<0,001)$. Naposljetku, povezanost SSS-a i spola ${ }^{18}$ je negativna $(\beta=-0,234 ; \mathrm{p}<0,001)$ što znači da studenti i dalje postižu više rezultate na SSS-u od studentica i kada se iz analize isključi utjecaj tradicionalnog seksizma i stavova o feminističkom pokretu.

Tablica 4. Hijerarhijska regresijska analiza SSS-a (ukupni N=355)

\begin{tabular}{|c|c|c|c|c|c|c|c|c|}
\hline & \multirow{4}{*}{ 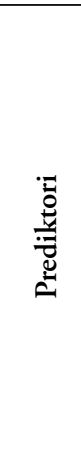 } & \multicolumn{7}{|c|}{ SSS } \\
\hline & & \multirow{3}{*}{ 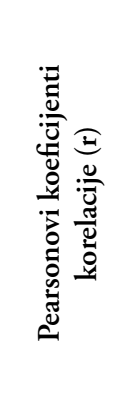 } & \multicolumn{3}{|c|}{ 1. korak } & \multicolumn{3}{|c|}{ 2. korak } \\
\hline & & & \multicolumn{2}{|c|}{ 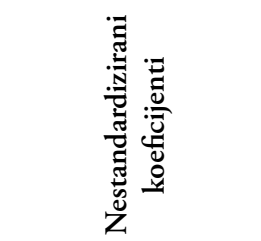 } & \multirow{2}{*}{ 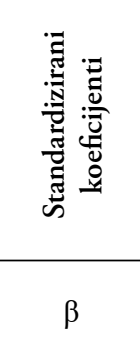 } & \multicolumn{2}{|c|}{ 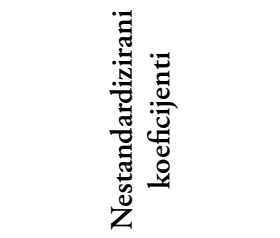 } & \multirow{2}{*}{ 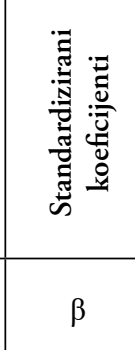 } \\
\hline & & & B & $\begin{array}{c}\text { Standardna } \\
\text { pogreška }\end{array}$ & & B & $\begin{array}{c}\text { Standardna } \\
\text { pogreška }\end{array}$ & \\
\hline \multirow{2}{*}{$\begin{array}{l}1 . \\
\text { korak }\end{array}$} & SSFP & $-0,790^{* *}$ & $-2,114$ & 0,127 & $-0,623^{* *}$ & $-1,876$ & 0,123 & $-0,553^{* *}$ \\
\hline & STS & $0,666^{* *}$ & 0,920 & 0,121 & $0,284^{* *}$ & 0,742 & 0,116 & $0,229^{* *}$ \\
\hline
\end{tabular}

18 Varijabla spol je kodirana na sljedeći način: 1 = muškarac; 2 = žena. 


\begin{tabular}{|c|c|c|c|c|c|c|}
\hline $\begin{array}{l}2 . \\
\text { korak }\end{array}$ & Spol & $-0,594^{* *}$ & & $-12,127$ & 1,663 & $-0,234^{* *}$ \\
\hline $\mathbf{R}^{2}$ & & & 0,677 & \multicolumn{3}{|c|}{0,720} \\
\hline$\Delta \mathrm{R}^{2}$ & & & 0,677 & \multicolumn{3}{|c|}{0,043} \\
\hline$F$ & & & $644,612^{* *}$ & \multicolumn{3}{|c|}{$698,317^{* *}$} \\
\hline
\end{tabular}

Napomena: ${ }^{* *} \mathrm{p}<0,01 ; \Delta R^{2}$ predstavlja povećanje $R^{2}$ nakon uključivanja novog prediktora u regresijsku jednadžbu.

Kako bismo dodano provjerili kriterijsku valjanost, uzimajući u obzir i valjanost poznatih grupa, tj. činjenicu da je suvremeni seksizam jače izražen među muškarcima, testirali smo i veze između tradicionalnog seksizma i stavova prema feminističkom pokretu $s$ rezultatima na SSS-u na poduzorcima muškaraca i žena zasebno radi dobivanja uvida u spolno specifične modele za tumačenje suvremenog seksizma.

Multivarijatna regresijska analiza na poduzorku muškaraca proizvela je dva modela. U posljednjem (drugom) modelu $\mathrm{R}^{2}$ je najveći te iznosi 0,678. Dakle, 67,8\% ukupne varijance kriterija (SSS-a) na poduzorku muškaraca objašnjeno je sa sljedeća dva prediktora: SSFP-om i STS-om.

Iz Tablice 5 možemo vidjeti kako je za studente SSFP najjači prediktor rezultata na SSS-u, a zatim slijedi STS. Povezanost SSS-a i SSFP-a negativnog je predznaka $(\beta=-$ $0,721 ; p<0,001)$, dok je povezanost SSS-a i STS-a pozitivna $(\beta=0,195 ; p<0,001)$. Iz iznosa beta koeficijenata moguće je zaključiti kako su suvremeni seksistički stavovi muškaraca najvećim dijelom određeni njihovim stavovima o feminističkom pokretu, a ipak nešto manje njihovim tradicionalnim seksističkim stavovima.

Tablica 5. Regresijska analiza SSS-a (samo muškarci; $N=89$ )

\begin{tabular}{|l|c|c|c|c|}
\hline \multirow{2}{*}{ Prediktori } & \multicolumn{4}{|c|}{ SSS } \\
\cline { 2 - 5 } & $\begin{array}{c}\text { Pearsonovi } \\
\text { koeficijenti } \\
\text { korelacije }(\mathrm{r})\end{array}$ & \multicolumn{2}{|c|}{ Nestandardizirani koeficijenti } & $\begin{array}{c}\text { Standardizirani } \\
\text { koeficijenti }\end{array}$ \\
\cline { 3 - 6 } & & B & $\begin{array}{c}\text { Standardna } \\
\text { pogreška }\end{array}$ & $\beta$ \\
\hline SSFP & $-0,804^{* *}$ & $-2,316$ & 0,218 & $-0,721^{* *}$ \\
\hline STS & $0,527^{* *}$ & 0,513 & 0,178 & $0,195^{* *}$ \\
\hline R & & & \multicolumn{3}{|c|}{0,678} \\
\hline F & & \multicolumn{3}{|c|}{$167,404^{* *}$} \\
\hline
\end{tabular}

Napomena: ${ }^{* *} \mathrm{p}<0,01$.

Multivarijatna regresijska analiza na poduzorku žena također je proizvela dva modela. $\mathrm{U}$ posljednjem (drugom) modelu $\mathrm{R}^{2}$ je najveći te iznosi 0,547. Dakle, 54,7\% ukupne varijance kriterija (SSS-a) na poduzorku žena, također je objašnjeno sa sljedeća dva pre- 
diktora: SSFP-om te STS-om. Iz Tablice 6 možemo vidjeti kako je za studentice SSFP najjači prediktor rezultata na SSS-u, a zatim slijedi STS. Povezanost SSS-a i SSFP-a negativnog je predznaka $(\beta=-0,523 ; \mathrm{p}<0,001)$, dok je povezanost SSS-a i STS-a pozitivna $(\beta=0,308 ; p<0,001)$. Iz iznosa beta koeficijenata moguće je zaključiti kako su, slično kao i kod muškaraca, suvremeni seksistički stavovi žena u najvećoj mjeri određeni njihovim stavovima prema feminističkom pokretu, a nešto manje njihovim tradicionalnim seksističkim stavovima.

Tablica 6. Regresijska analiza SSS-a (samo žene; $N=266$ )

\begin{tabular}{|l|c|c|c|c|}
\hline \multirow{2}{*}{ Prediktori } & \multicolumn{4}{|c|}{ SSS } \\
\cline { 2 - 5 } & $\begin{array}{c}\text { Pearsonovi } \\
\text { koeficijenti } \\
\text { korelacije (r) }\end{array}$ & \multicolumn{2}{|c|}{ Nestandardizirani koeficijenti } & $\begin{array}{c}\text { Standardizirani } \\
\text { koeficijenti }\end{array}$ \\
\cline { 3 - 5 } & $-0,694^{* *}$ & $-1,592$ & $\begin{array}{c}\text { Standardna } \\
\text { pogreška }\end{array}$ & $\beta$ \\
\hline SSFP & $0,600^{* *}$ & 0,965 & 0,152 & $-0,156$ \\
\hline STS & & \multicolumn{4}{|c}{$0,523^{* *}$} \\
\hline $\mathbf{R}^{2}$ & & \multicolumn{4}{|c|}{$283,126^{* *}$} \\
\hline F & & \multicolumn{4}{|c|}{} \\
\hline
\end{tabular}

\section{DISKUSIJA}

Suvremeni seksizam u ovoj je studiji definiran kao odobravanje suvremenih diskriminatornih i predrasudnih stavova o ženama u privatnoj i javnoj sferi u četiri sadržajne domene: nijekanje postojanja daljnje diskriminacije žena, antagonizam spram zahtjeva žena, ogorčenje zbog posebnih pogodnosti koje žene dobivaju samo zbog toga što su žene te zamjeranje ženama zbog „preosjetljivosti“ na seksizam i seksualno uznemiravanje. Na temelju takve konceptualizacije, konstruiran je novi mjerni instrument te se ovdje osvrćemo na rezultate vezane za njegovu validaciju na prigodnom uzorku studentica i studenata Sveučilišta u Zagrebu.

Analiza interne konzistentnosti pokazala je kako je novokonstruirana SSS koja se sastoji od 27 čestica visoko pouzdana $(\alpha=0,966)$, dok sve ostale provedene analize govore $u$ prilog njenoj valjanosti.

Analiza dimenzionalnosti skale rezultirala je prvo s tri komponente (prema GK kriteriju), a potom $s$ dvije komponente (u paralelnoj analizi). Komponente su prema sadržaju interpretabilne te možemo reći kako se suvremeni seksistički stavovi u ovoj studiji sastoje od dviju skupina međusobno povezanih sadržaja. Prvu skupinu čine različiti antagonizmi spram zahtjeva, prava i pogodnosti koje žene, prema onima koji iskazuju suvremene seksističke stavove, traže i dobivaju samo zbog toga što su žene, kao i na nijekanje relevantnosti problema nasilja nad ženama u obitelji, dok se druga skupina 
sadržaja odnosi na nijekanje daljnje diskriminacije i neravnopravnosti žena u različitim područjima, kako u privatnoj tako i u javnoj sferi. Analiza dimenzionalnosti SSS-a vođena kriterijima koje su postavili Carmines i Zeller (1979), potvrdila je konceptualno pretpostavljanu jednodimenzionalnost predmeta mjerenja, što govori u prilog jednoj od podvrsta konstruktne valjanosti - faktorskoj valjanosti. Visoke interkorelacije dobivenih komponenata koje nisu uobičajene u oblimin transformacijama dodatno podržavaju pretpostavku jednodimenzionalnosti, kao i rezultat hijerarhijske analize glavnih komponenata koja je također rezultirala jednom komponentom. Stoga, možemo zaključiti kako konačna inačica SSS-a, koju čini 27 čestica, mjeri jedan predmet mjerenja te je možemo tretirati kao jednodimenzionalnu skalu Likertova tipa. No, s obzirom na dvije utvrđene i interpretabilne skupine sadržaja koji čine ovu skalu, ostavljamo mogućnost da je suvremeni seksizam moguće konceptualno sagledati i kao dvodimenzionalan fenomen. Iako su potrebna dodatna istraživanja i analize za testiranje ove teze, ostavljamo otvorenu i mogućnost za korištenje odvojenih subskala za mjerenje svake od ovih dviju skupina sadržaja unutar koncepta suvremenog seksizma, ovisno o potrebama istraživača u budućim studijama. U tom slučaju, SSS se može koristiti i kao dvodimenzionalna skala $s$ dvije pozitivno povezane subskale, od kojih jedna mjeri sadržaje vezane za antagonizme prema ženskim zahtjevima i naporima u postizanju rodne ravnopravnosti, a druga nijekanje daljnje diskriminacije i neravnopravnosti žena. Svaka subskala SSS-a zasebno ima također izvrsnu pouzdanost (prema Kline, 1998 i George i Mallery, 2003). Osvrtom na sadržajnu valjanost, autori su uvidjeli da jedan manji dio sadržaja vezan za privatnu, obiteljsku sferu, i to onaj koji se odnosi na raspodjelu kućanskih poslova te raspodjelu poslova oko odgoja i brige o djeci, treba biti isključen iz skale zbog neadekvatne formulacije dviju čestica. Ostaje otvorenim je li zagovaranje koncepta „pomaganja muškaraca u kućanskim poslovima" (koji je u suprotnosti s konceptom ravnopravne raspodjele kućanskih poslova između oba partnera) adekvatno smatrati pokazateljem suvremenog seksizma ili je to pak njemu blizak, ali ipak samostalan koncept koji zahtijeva konstrukciju zasebnog mjernog instrumenta.

Analiza kriterijske valjanosti SSS-a na temelju valjanosti poznatih grupa provedena je testiranjem hipoteze da će muškarci postizati više rezultate na toj skali nego žene. Ta je pretpostavka potvrđena uz relativno veliku razliku prosječnih rezultata muškaraca i žena.

Procjena konvergentne valjanosti utemeljena je u testiranju hipoteza da će rezultati na SSS-u biti umjereno pozitivno povezani s tradicionalnim seksizmom i umjereno negativno sa stavovima o feminističkom pokretnu. Ove su hipoteze potvrđene, uz utvrđivanje čak nešto snažnijih veza od onih u prethodnim istraživanjima (Swim i sur., 1995; Tougas i sur., 1995, Campbell i sur., 1997; Conn i sur., 1999), i to u predviđenom smjeru. Multivarijatne analize pokazale su da je povezanost rezultata na SSS-u i spola negativna $(\beta=-0,234)$, što znači da studenti postižu više rezultate na SSS-u od studentica kada se iz analize isključi utjecaj tradicionalnog seksizma i stavova o feminističkom pokretu. Ovim smo nalazom potvrdili i prvu izvedenu hipotezu ovog rada, odnosno da muškarci postižu više rezultate na SSS-u od žena, čak i kad se isključi utjecaj tradicio- 
nalnog seksizma i stavova o feminističkom pokretu. Uspoređujući nalaze multivarijatne regresijske analize na svakom poduzorku ispitanika prema spolu, možemo istaknuti kako se dobiveni modeli ne razlikuju previše između muškog i ženskog poduzorka jer su se prediktorima u oba slučaja pokazali i stavovi prema feminističkom pokretu i tradicionalni seksistički stavovi, pri čemu su oni prvi nešto snažniji prediktor. No, određena razlika između spolno specifičnih modela ipak postoji jer je postotak protumačene varijance u muškom poduzorku nešto veći, odnosno prediktorski sklop kod muškaraca nešto bolje tumači varijancu suvremenog seksizma u odnosu na žene. Također, stavovi prema feminističkom pokretu nešto su jači prediktor suvremenog seksizma među muškarcima, a tradicionalni seksizam među ženama. Navedeni rezultati idu u prilog prihvaćanja druge izvedene hipoteze u kojoj se tvrdilo da su suvremeni seksistički stavovi pozitivno povezani s tradicionalnim seksističkim stavovima, a negativno sa stavovima o feminističkom pokretu, kako na objedinjenom uzorku tako i na poduzorcima muškaraca i žena zasebno. To nas navodi na zaključak kako je konvergentna valjanost ove skale zadovoljavajuća.

Nadalje, nismo predvidjeli koliku će važnost u predikciji suvremenih seksističkih stavova imati stavovi studenata prema feminističkom pokretu koji tumače preko $60 \%$ ukupne varijance suvremenog seksizma na ukupnom uzorku studenata, a gotovo $2 / 3$ ukupne varijance suvremenih seksističkih stavova na poduzorku (muških) studenata (na ženskom poduzorku nešto manje, ali ipak gotovo polovicu ukupne varijance suvremenih seksističkih stavova). Osim toga, samo tri prediktora (stavovi prema feminističkom pokretu, spol i tradicionalni seksizam) u našim modelima zajedno tumače preko $70 \%$ ukupne varijance suvremenog seksizma što je za istraživanja u društvenim znanostima, $\mathrm{u}$ kojima je neki složeni fenomen vrlo teško objasniti malim brojem prediktorskih varijabli, izrazito visok postotak. Stoga, možemo zaključiti da su, prema rezultatima ovog rada, suvremeni seksistički stavovi u najvećoj mjeri određeni stavovima prema feminističkom pokretu studentica i studenata, a nešto manje njihovim spolom i tradicionalnim seksističkim stavovima.

\subsection{Ograničenja studije}

Potrebno se osvrnuti i na ograničenja ove studije u konstrukciji i validaciji predstavljene Skale suvremenog seksizma. Prvo, iako oslanjanje na predloženu konceptualizaciju, odnosno četiri sadržajne domene od kojih smo krenuli u operacionalizaciju i konstrukciju SSS-a, smatramo korisnim zbog zahvaćanja većine tema koje su ključne za mjerenje različitih oblika suvremenog seksizma (modernog seksizma Swim i sur., 1995, neoseksizma Tougas i sur., 1995 te ambivalentnog seksizma Glicka i Fiske, 1996), valja istaknuti da niti ovakva konceptualizacija ne zahvaća sve moguće aspekte suvremenog seksizma. U ovoj studiji bavili smo se suvremenim seksizmom u određenim područjima društvenog života žena i muškaraca, ali ne u svima jer, primjerice, unutar naše konceptualizacije nedostaje tematika reproduktivnih praksi, prava i statusa kako žena tako i parova. Drugo, u ovom radu u potpunosti izostaje provjera diskriminativne valjanosti SSS-a zbog 
toga što u našoj studiji nije mjeren konstrukt za kojeg bi se očekivala nepovezanost sa SSS-om. Treće, uzorak na kojem je istraživanje provedeno bio je prigodan uzorak dijela studentske populacije, a poznato je kako studentske populacije karakterizira viši stupanj obrazovanja, viši socioekonomski i sociokulturni status, bolje socijalno porijeklo te niži stupanj religioznosti u odnosu na ostale podskupine mladih, ali i opće populacije (Ilišin, 2014; Boneta, 2016). Već sama priroda neprobabilističkog uzorkovanja, a pogotovo jedne ovako specifične populacije, zasigurno predstavlja određeno ograničenje u mogućnostima generalizacije dobivenih nalaza na neke druge populacije.

\subsection{Preporuke za buduća istraživanja}

Diskusija o dimenzionalnosti samog koncepta suvremenog seksizma, kao i prvo navedeno ograničenje studije vezano za izostavljanje određenih tema iz konceptualizacije predmeta mjerenja, ukazuje na potrebu za nastavkom teorijskog i metodološkog rada te empirijskog proučavanja fenomena suvremenog seksizma i njegovih potencijalnih promjena kroz vrijeme, kao i načina na koji oni zavise o društvenom kontekstu i aktualnim društvenim i političkim zbivanjima. Nastavno na drugo navedeno ograničenje studije, preporuka za buduća istraživanja jest i uključivanje konstrukta za kojeg se očekuje nepovezanost sa suvremenim seksističkim stavovima kako bi se dodatno upotpunila validacija SSS-a provjerom diskriminativne valjanosti. U skladu s trećim ograničenjem studije, posebice je važno dodatno validirati skalu na uzorcima drugih populacija, a ne samo na studentskoj populaciji. S obzirom na to da završna inačica skale u ovoj studiji ima 27 čestica, što je čini relativno dugačkim mjernim instrumentom, autori takoder predlažu daljnji rad na njezinom potencijalnom skraćivanju, no uz zadržavanje što je moguće većeg broja relevantnih sadržaja prema predloženoj konceptualizaciji u četiri sadržajne domene, u javnoj i privatnoj sferi. Osim toga, na podacima prikupljenim na reprezentativnijem uzorku, posebice onom opće populacije, uz nastavak procjene kvalitete mjernog instrumenta, mogli bi se donositi i znatno bolje utemeljeni zaključci o tome što stoji u pozadini ovog fenomena, a usporedno s time bi se onda trebao utvrditi i obuhvatniji prediktorski sklop suvremenog seksizma.

\section{ZAKLJUČAK}

Ovaj rad nastoji pridonijeti obuhvatnijem razmatranju seksizma u današnjem hrvatskom društvu, tj. upotpuniti teorijske, metodološke i empirijske spoznaje vezane uz fenomen seksizma u hrvatskoj sociologiji. U suvremenoj istraživačkoj praksi domaćih sociologinja i sociologa mjerenje seksizma, a moguće i njegovo shvaćanje, i dalje se primarno odnosi na tradicionalni seksizam. No, istraživanja pokazuju generalno smanjenje izmjerenog stupnja (tradicionalnog) seksizma, posebice među mladima (Forbes i sur., 2004), a ti se nalazi mogu tumačiti, kako to čine primjerice McHugh i Frieze (1997), na način da nije isključivo riječ o stvarnom padu razine seksističkih uvjerenja u nekom društvu, već o njihovoj transformaciji. Naime, uspjesi feminističkih pokreta doveli su 
do toga da je izražavanje seksističkih stavova postalo društveno neprihvatljivo, pa se sam opseg i fokus seksizma kroz vrijeme promijenio (Klasnić i Štulhofer, 2018). Stoga je moguće, kako navode Klasnić i Štulhofer (2018: 226), da „instrumenti koji mjere tradicionalne oblike seksizma, zbog svoje izravnosti u mjerenju i eksplicitno seksističkih čestica danas više ne mogu valjano izmjeriti seksističke stavove".

Osvrtom na već postojeće skale različitih tipova suvremenog seksizma, u ovu studiju krenuli smo od pretpostavke da je različite suvremene oblike seksizma - pri čemu ponajprije mislimo na koncept modernog seksizma Swim i suradnica (1995), neoseksizma Tougas i suradnika (1995) te neprijateljskog seksizma Glicka i Fiske (1996) - moguce objediniti pod nadređenim pojmom suvremenog seksizma. Primjenom inovativne i obuhvatne konceptualno-operacionalne razrade predmeta mjerenja suvremenog seksizma, konstruirali smo pouzdan i valjan mjerni instrument koji mjeri jedan predmet mjerenja, a to su suvremeni seksistički stavovi, tj. odobravanje suvremenih diskriminatornih i predrasudnih stavova o ženama, koji nisu bili zahvaćeni dosadašnjim empirijskim istraživanjima na hrvatskoj sociološkoj sceni. Predlažemo da se konstruirana skala nastavi koristiti kao mjera suvremenog seksizma u istraživanjima koja se bave temama rodne neravnopravnosti i diskriminacije žena. $S$ obzirom na to da jedna studija ne može u potpunosti dokazati valjanost nekog novog mjernog instrumenta, već je za to potreban kontinuirani proces evaluacije, reevaluacije, dorađivanja i razvoja skale (Touliatos i sur., 1990), naglašavamo i važnost daljnjeg, kako teorijskog tako i empirijsko-metodološkog rada na ovoj temi.

\section{LITERATURA}

Barada, V. i Jelavić, Ž. (2004). Uostalom, diskriminaciju treba dokinuti! Priručnik za analizu rodnih stereotipa. Zagreb: Centar za ženske studije.

Beaton, A., Tougas, F. i Joly, S. (1996). Neosexism Among Male Managers: Is it a Matter of Numbers? Journal of Applied Social Psychology, 26(24): 2189-2203.

Boneta, Ž. (2016). Klatno se i dalje njiše. Institucionalna religioznost riječkih studenata. Sociologija i prostor, 54(3): 265-294.

Brenan, M. (2019). U.S. Men Less Concerned than in 2017 About Sexual Harassment. Gallup, 18. ožujka 2019. URL: https://news.gallup.com/poll/247823/men-less-concerned-2017-sexual-harassment.aspx?utm_source=alert\&utm_medium=email\&utm_content=morelink\&utm_campaign=syndication $(26.01 .2021$.)

Campbell, B., Schellenberg, E. G. i Senn, C. Y. (1997). Evaluating Measures of Contemporary Sexism. Psychology of Women Quarterly, 21(1): 89-102.

Carmines, E. G. i Zeller, R. A. (1979). Reliability and Validity Assessment. Beverly Hills, CA: Sage Publications.

Conn, A. B., Hanges, P. J., Sipe, W. P. i Salvaggio, A. N. (1999). The Search for Ambivalent Sexism: A Comparison of Two Measures. Educational and Psychological Measurement, 59(6): 898-909. 
Čulig, B., Kufrin, K. i Landripet, I. (2007). EU +?-: Odnos gradana Hrvatske prema pridruživanju Republike Hrvatske Europskoj uniji. Zagreb: FF press i Grupa za ženska ljudska prava B.a.B.e.

Ekehammar, B., Akrami, N. i Araya, T. (2000). Development and Validation of Swedish Classical and Modern Sexism Scale. Scandinavian Journal of Psychology, 41(4): 307-314.

Fassinger, R. E. (1994). Development and Testing of the Attitudes Toward Feminism and the Women's Movement (FWM) Scale. Psychology of Women Quarterly, 18(3): 389-402.

Forbes, G. B., Adams-Curtis, L. E. i White, K. B. (2004). First- and Second-Generation Measures of Sexism, Rape Myths and Related Beliefs, and Hostility Toward Women: Their Interrelationships and Association with College Students' Experiences with Dating Aggression and Sexual Coercion. Violence Against Women, 10(3): 236-261.

Galić, B. (2008). Rodni identitet i seksizam u Hrvatskoj. U: Cifrić, I. (ur.), Relacijski identiteti: Prilozi istraživanju identiteta hrvatskog društva (str. 153-183). Zagreb: Biblioteka Razvoj i okoliš.

Galić, B. (2012). Promjena seksističkog diskursa u Hrvatskoj? Usporedba rezultata istraživanja 2004. i 2010. godine. Socijalna ekologija, 21(2): 155-177.

Galić, B. i Klasnić, K. (2012). Seksizam i socioekološke orijentacije u Republici Hrvatskoj. U: Drezgić, R., Duhaček, D. i Vasiljević, J. (ur.), Ekofeminizam: Nova politička odgovornost (str. 172-200). Beograd: Institut za filozofiju i društvenu teoriju, Univerzitet u Beogradu.

Galić, B. i Nikodem, K. (2006). Ne/razlomljeni identiteti: Seksizam i religioznost u hrvatskom društvu. Socijalna ekologija, 15(1-2): 81-102.

Gaskin, C. J. i Hapell, B. (2014). On Exploratory Factor Analysis: A Review of Recent Evidence, an Assessment of Current Practice, and Recommendations for Future Use. International Journal of Nursing Studies, 51(3): 511-521.

George, D. i Mallery, P. (2003). SPSS for Windows Step by Step: A Simple Guide and Reference 11.0 Update. Boston, MA: Allyn \& Bacon.

Glick, P. i Fiske, S. T. (1996). The Ambivalent Sexism Inventory: Differentiating Hostile and Benevolent Sexism. Journal of Personality and Social Psychology, 70(3): 491-512.

Glick, P., Lameiras, M. i Castro, Y. R. (2002). Education and Catholic Religiosity as Predictors of Hostile and Benevolent Sexism Toward Women and Men. Sex Roles, 47(9-10): 433-441.

Glick, P. i Fiske, S. T. (2011). Ambivalent Sexism Revisited. Psychology of Women Quarterly, 35(3): 530-535.

Hair, J. F., Black, W. C., Babin, B. J. i Anderson, R. E. (2014). Multivariate Data Analysis: Pearson New International Edition. Harlow: Pearson.

Huber, K. A. (2016). Sexism Goes Underground: The Development of a Neosexism Scale Catered to College Student Populations. Lake Forest, IL: Lake Forest College Publications.

Informacijski sustav visokih učilišta - ISVU (2020). Pregled sustava: Studenti. URL: https://www.isvu.hr/sustav/studenti (17.12.2020.) 
Ilišin, V. (2014). Završna rasprava. U: Ilišin, V. (ur.), Sociološki portret hrvatskih studenata (str. 421-438). Zagreb: Institut za društvena istraživanja u Zagrebu.

Klasnić, K. (2014). Konstrukcija i evaluacija skala namijenjenih mjerenju prepoznavanja i iskustava ekonomskog nasilja nad ženama u intimnim vezama (doktorska disertacija). Zagreb: Filozofski fakultet Sveučilišta u Zagrebu.

Klasnić, K. (2017). Utjecaj rodne podjele obiteljskih obveza i kućanskih poslova na profesionalni život zaposlenih žena. Zagreb: Pravobranitelj/ica za ravnopravnost spolova Republike Hrvatske.

Klasnić, K. i Štulhofer, A. (2018). Prihvaćanje mitova o silovanju među adolescentima: longitudinalna medijacijska studija. Društvena istraživanja, 27(2): 221-242.

Kline, R. B. (1998). Principles and Practice of Structural Equation Modeling. New York, NY: The Guilford Press.

Masser, B. i Abrams, D. (1999). Contemporary Sexism: The Relationship Among Hostility, Benevolence, and Neosexism. Psychology of Women Quarterly, 23(3): 503517.

McHugh, M. C. i Frieze, I. H. (1997). The Measurement of Gender-Role Attitudes: A Review and Commentary. Psychology of Women Quarterly, 21(1): 1-16.

Morrison, M. A., Morrison, T. G., Pope, G. A. i Zumbo B. D. (1999). An Investigation of Measures of Modern and Old-Fashioned Sexism. Social Indicators Research, 48(1): 39-50.

Nunnally, J. C. i Bernstein, I. H. (1994). Psychometric Theory. New York, NY: McGraw-Hill.

Rupp, A. A. i Pant, Hans A. (2007). Validity Theory. U: Salkind, N. J. (ur.), Encyclopedia of Measurement and Statistics (str. 1032-1035). Thousand Oaks, CA: Sage Publications.

Spector, E. P. (1992). Summated Rating Scale Construction. Sage University Paper Series on Quantitative Applications in the Social Sciences, No. 07-082. Newbury Park, CA: Sage publications.

Spence, J. T., Helmreich, R. i Stapp, J. (1973). A Short Version of the Attitudes Toward Women Scale (AWS). Bulletin of the Psychonomic Society, 2(4): 219-220.

Spence, J. T. i Hahn, E. (1997). The Attitudes Toward Women Scale and Attitude Change in College Students. Psychology of Women Quarterly, 21(1): 17-34.

Stoll, L. C., Lilley, T. G. i Pinter, K. (2017). Gender-Blind Sexism and Rape Myth Acceptance. Violence Against Women, 23(1): 28-45.

Swim, J. K., Aikin, K. J., Hall, W. S. i Hunter, B. A. (1995). Sexism and Racism: Old-Fashioned and Modern Prejudices. Journal of Personality and Social Psychology, 68(2): 199-214.

Swim, J. K. i Cohen, L. L. (1997). Overt, Covert, and Subtle Sexism: A Comparison Between the Attitudes Toward Women and Modern Sexism Scales. Psychology of Women Quarterly, 21(1): 103-118.

Tomić-Koludrović, I. i Kunac, S. (2000). Rizici modernizacije: žene u Hrvatskoj devedesetih. Split: Stope nade. 
Topolčić, D. (2001). Muškarci to ne rade: rodno segregirana podjela rada u obitelji. Društvena istraživanja, 10(4-5): 767-789.

Tougas, F., Brown, R., Beaton, A. M. i Joly, S. (1995). Neosexism: Plus Ca Change, Plus C'est Pareil. Journal of Personality and Social Psychology, 21(8): 842-849.

Touliatos, J., Perlmutter, B. F. i Straus, M. A. (1990). Handbook of Family Measurement Techniques. Newbury Park, CA: Sage Publications.

Ustav Republike Hrvatske. Narodne novine, br. 56/1990, 135/1997, 8/1998, 113/2000, 124/2000, 28/2001, 41/2001, 55/2001, 76/2010, 85/2010, 5/2014.

Walby, S. (2005). Rodne preobrazbe. Zagreb: Ženska infoteka. 


\section{Prilog 1. Skala suvremenog seksizma (SSS)}

Uputa za ispunjavanje instrumenta (potka): Tvrdnje koje slijede odnose se na različite aspekte stavova o odnosu muškaraca i žena u današnjem društvu. Molimo Vas da kraj svake od navedenih tvrdnji odaberete jedan broj koji najbolje opisuje u kojoj se mjeri Vi osobno slažete sa sadržajem svake od njih.

Skala procjene: 1 - „Uopće se ne slažem“; 2 - „Ne slažem se“; 3 - „Niti se slažem, niti se ne slažem“; 4 - „Slažem se“; 5 - „U potpunosti se slažem“

Uputa istraživačima: nasumični redoslijed čestica u anketnom upitniku, ako je moguće (npr. u online anketiranjima) poželjno je varirati njihov redoslijed.

\begin{tabular}{|c|c|c|c|}
\hline $\begin{array}{l}\stackrel{\pi}{\Xi} \\
\stackrel{\Xi}{0}\end{array}$ & 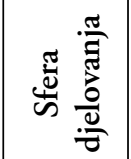 & Indikator & Čestica za anketni upitnik \\
\hline \multirow{10}{*}{ 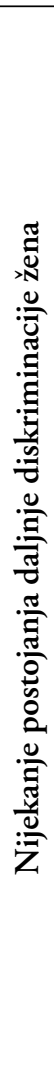 } & $\begin{array}{c}\text { Privatna } \\
\text { i javna }\end{array}$ & $\begin{array}{l}\text { Postignuta rodna } \\
\text { ravnopravnost }\end{array}$ & $\begin{array}{l}\text { U suvremenim zapadnim društvima žene su već } \\
\text { postigle ravnopravnost, pa je daljnja rasprava o } \\
\text { pravima žena nepotrebna. }\end{array}$ \\
\hline & $\begin{array}{c}\text { Privatna } \\
\text { i javna }\end{array}$ & $\begin{array}{l}\text { Jednak način odnošenja } \\
\text { spram dvaju spolova }\end{array}$ & $\begin{array}{l}\text { Današnje hrvatsko društvo muškarce } i \text { žene tretira } u \\
\text { potpunosti ravnopravno. }\end{array}$ \\
\hline & Javna & $\begin{array}{l}\text { Izostanak diskriminacije } \\
\text { žena na tržištu rada }\end{array}$ & $\begin{array}{c}\text { Diskriminacija žena na tržištu rada više nije problem } \\
\text { hrvatskog društva. }\end{array}$ \\
\hline & Privatna & $\begin{array}{l}\text { Izostanak diskriminacije } \\
\text { žena u obitelji }\end{array}$ & $\begin{array}{c}\text { Diskriminacija žena u obitelji više nije problem u } \\
\text { Hrvatskoj. }\end{array}$ \\
\hline & Javna & $\begin{array}{l}\text { Pravednost sustava } \\
\text { zapošljavanja }\end{array}$ & $\begin{array}{c}\text { Hrvatski sustav zapošljavanja nepravedan je prema } \\
\text { ženama. }\end{array}$ \\
\hline & Javna & $\begin{array}{l}\text { Diskriminacija prema } \\
\text { spolu nije uzrok razlika u } \\
\text { plaćama }\end{array}$ & $\begin{array}{c}\text { Razlike u plaćama muškaraca i žena za isti } \\
\text { posao rezultat su različitog radnog učinka, a ne } \\
\text { diskriminacije prema spolu. }\end{array}$ \\
\hline & Javna & $\begin{array}{c}\text { Jednake mogućnosti za } \\
\text { postizanje poslovnog } \\
\text { uspjeha }\end{array}$ & $\begin{array}{c}\text { U današnjem hrvatskom društvu muškarci i žene } \\
\text { imaju jednake mogućnosti postići uspješnu poslovnu } \\
\text { karijeru. }\end{array}$ \\
\hline & Javna & $\begin{array}{l}\text { Jednaka dostupnost } \\
\text { vodećih društvenih } \\
\text { položaja }\end{array}$ & $\begin{array}{l}\text { Vodeći položaji u politici i gospodarstvu i dalje nisu } \\
\text { jednako dostupni ženama i muškarcima. }{ }^{*}\end{array}$ \\
\hline & Javna & $\begin{array}{l}\text { Dovoljna zastupljenost } \\
\text { žena u politici i javnom } \\
\text { životu } \\
\end{array}$ & $\begin{array}{c}\text { U Hrvatskoj premalo žena sudjeluje u politici i } \\
\text { javnom životu. * }\end{array}$ \\
\hline & Privatna & $\begin{array}{l}\text { Nezahvalnost žena prema } \\
\text { njihovim muževima }\end{array}$ & $\begin{array}{c}\text { Većina žena ne cijeni dovoljno sve ono što njihovi } \\
\text { muževi rade za njih. }\end{array}$ \\
\hline
\end{tabular}




\begin{tabular}{|c|c|c|c|}
\hline \multirow{6}{*}{ 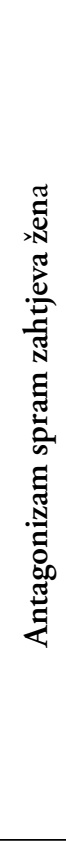 } & $\begin{array}{c}\text { Privatna } \\
\text { i javna }\end{array}$ & $\begin{array}{c}\text { Žene dobivaju više prava } \\
\text { nego što zaslužuju }\end{array}$ & $\begin{array}{c}\text { Uposljednjih nekoliko godina, žene ostvaruju više } \\
\text { prava nego što zaslužuju. }\end{array}$ \\
\hline & Javna & $\begin{array}{l}\text { Mediji posvećuju previše } \\
\text { pažnje ženskim zahtjevima }\end{array}$ & $\begin{array}{c}\text { Uposljednje vrijeme mediji posvećuju previše prostora } \\
\text { zahtjevima žena. }\end{array}$ \\
\hline & $\begin{array}{l}\text { Privatna } \\
\text { i javna }\end{array}$ & $\begin{array}{l}\text { Pomoću rodne } \\
\text { ravnopravnosti žene } \\
\text { dolaze do posebnih } \\
\text { pogodnosti }\end{array}$ & $\begin{array}{l}\text { Pod krinkom spolne ravnopravnosti žene zapravo } \\
\text { pokušavaju ostvariti posebne pogodnosti. }\end{array}$ \\
\hline & $\begin{array}{l}\text { Privatna } \\
\text { i javna }\end{array}$ & $\begin{array}{l}\text { Ženske udruge traže veća } \\
\text { prava za žene nego što ih } \\
\text { imaju muškarci }\end{array}$ & $\begin{array}{c}\text { Ženske udruge u stvari za žene traže veća prava od } \\
\text { prava koja imaju muškarci. }\end{array}$ \\
\hline & Javna & $\begin{array}{c}\text { Zbog izbjegavanja naslova } \\
\text { seksista poslodavci } \\
\text { prekomjerno udovoljavaju } \\
\text { ženskim zahtjevima }\end{array}$ & $\begin{array}{c}\text { Kako ih se ne bi proglasilo seksistima, mnogi } \\
\text { su poslodavci skloni prekomjerno udovoljavati } \\
\text { zahtjevima svojih zaposlenica. }\end{array}$ \\
\hline & $\begin{array}{l}\text { Privatna } \\
\text { i javna }\end{array}$ & $\begin{array}{l}\text { Pretjeranost ženskih } \\
\text { zahtjeva za rodnu } \\
\text { ravnopravnost }\end{array}$ & $\begin{array}{c}\text { Vecina zahtjeva žena u smislu ravnopravnosti spolova } \\
\text { jednostavno je pretjerana. }\end{array}$ \\
\hline \multirow{8}{*}{ 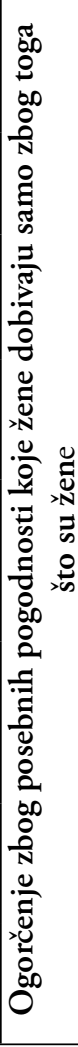 } & $\begin{array}{c}\text { Privatna } \\
\text { i javna }\end{array}$ & $\begin{array}{c}\text { Pretjerana rasprava o } \\
\text { nepravednom postupanju } \\
\text { prema ženama }\end{array}$ & $\begin{array}{l}\text { U posljednjih nekoliko godina vlast i mediji pokazuju } \\
\text { veću zabrinutost oko nepravednog postupanja prema } \\
\text { ženama nego sto je to u stvarnosti potrebno. }\end{array}$ \\
\hline & Privatna & $\begin{array}{l}\text { Mediji posvećuju previše } \\
\text { pažnje nasilju nad ženama }\end{array}$ & $\begin{array}{c}\text { Uposljednje vrijeme mediji posvećuju previše prostora } \\
\text { nasilju nad ženama u obitelji. }\end{array}$ \\
\hline & Javna & \begin{tabular}{|c} 
Vladajući se dovoljno bave \\
udovoljavanjem ženskim \\
zahtjevima
\end{tabular} & $\begin{array}{c}\text { Vlast ne stavlja dovoljan naglasak na rješavanje } \\
\text { problema neravnopravnosti žena na radnim } \\
\text { mjestima. }{ }^{*}\end{array}$ \\
\hline & Privatna & $\begin{array}{c}\text { Vladajući pretjerano } \\
\text { naglašavaju problem } \\
\text { nasilja nad ženama }\end{array}$ & $\begin{array}{c}\text { Uposljednje vrijeme vlast posvećuje previše pažnje } \\
\text { nasilju nad ženama u obitelji. }\end{array}$ \\
\hline & Javna & $\begin{array}{c}\text { Zbog rodne } \\
\text { ravnopravnosti } \\
\text { poslodavci zapošljavaju } \\
\text { nekvalificirane žene } \\
\end{array}$ & $\begin{array}{c}\text { Zbog pritiska ideje o spolnoj ravnopravnosti, } \\
\text { poslodavci često moraju zapošljavati nedovoljno } \\
\text { kvalificirane žene. }\end{array}$ \\
\hline & Javna & $\begin{array}{l}\text { Nepodržavanje uvođenja } \\
\text { strožih zakonskih odredbi } \\
\text { za rodnom ravnopravnosti } \\
\text { na radnim mjestima } \\
\end{array}$ & $\begin{array}{l}\text { Treba uvesti strože zakonske odredbe kako bi se zaista } \\
\text { postigla ravnopravnost spolova na radnim mjestima. * }\end{array}$ \\
\hline & Privatna & $\begin{array}{c}\text { Lažno optuživanje } \\
\text { muškaraca zbog zakona } \\
\text { koji pretjerano štite žene }\end{array}$ & $\begin{array}{c}\text { Zbog zakona koji služe zaštiti žena, mnogi muškarci } \\
\text { su lažno optuženi za nasilje u obitelji. }\end{array}$ \\
\hline & $\begin{array}{l}\text { Privatna } \\
\text { i javna }\end{array}$ & $\begin{array}{l}\text { Nepravednost politika } \\
\text { rodne ravnopravnosti } \\
\text { spram muškaraca }\end{array}$ & $\begin{array}{l}\text { Politike za postizanje spolne ravnopravnosti } \\
\text { nepravedne su prema muškarcima. }\end{array}$ \\
\hline
\end{tabular}




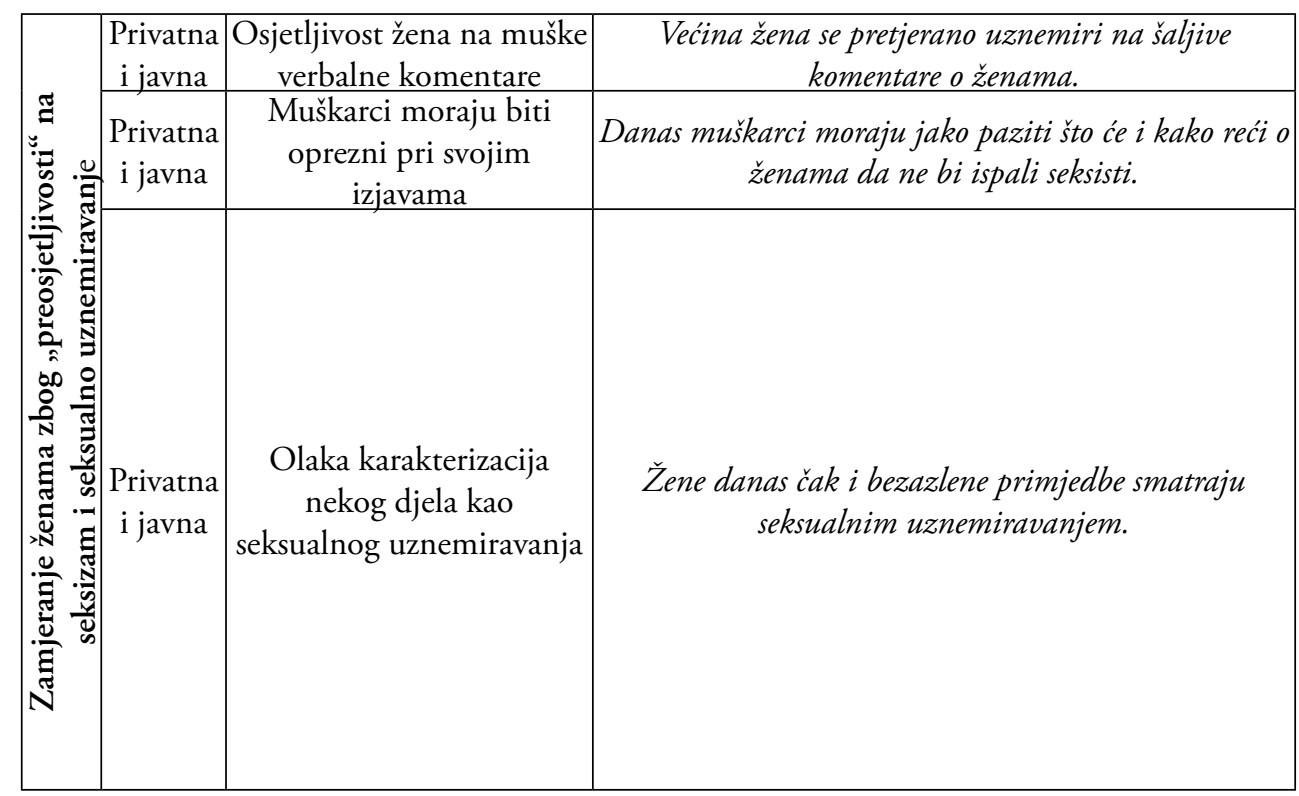

* označava negativne čestice (potrebno učiniti refleksiju skale prije konstrukcije aditivne skale) 


\title{
WHAT ELSE DO THEY WANT? DEVELOPMENT OF A NEW SCALE FOR MEASURING CONTEMPORARY FORMS OF SEXISM
}

\author{
Bruno Šimac and Ksenija Klasnić
}

\begin{abstract}
Prejudice against women, in the form of sexism, has traditionally been characterized by advocating stricter gender roles. However, due to cultural and political changes in the recent decades, overt discrimination against women became socially unacceptable, so sexism is taking on new, contemporary forms that often go unnoticed and remain secret and hidden. The aim of this paper is to construct and evaluate a new Scale of contemporary sexism that will bring together several so far conceptually separated forms of contemporary sexism, as well as some topics that have not been included in the existing scales of contemporary forms of sexism. Relying on three types of conceptual and operational elaborations of contemporary sexism - modern sexism by Swim et al. (1995), neosexism by Tougas et al. (1995), and ambivalent sexism by Glick and Fiske (1996), we conceptualize and operationalize contemporary sexist attitudes according to four basic domains: 1. denial of the existence of continued discrimination against women; 2. antagonism towards women's demands; 3. resentment of special benefits that women receive because they are women; and 4. resentment of women for their "hypersensitivity" to sexism and sexual harassment. The research was conducted using the survey method on a convenient sample of 402 students at the University of Zagreb. The final version of the Scale of Contemporary Sexism (SCS) is a one-dimensional measurement construct consisting of 27 particles. Based on the analyses, the authors conclude that SCS is an instrument of high reliability and satisfactory content, criterion, and constructive validity, and suggest some guidelines for its use in future survey research.
\end{abstract}

Keywords: discrimination of women, gender inequality, Scale of Contemporary Sexism (SCS), contemporary sexism, traditional sexism, attitudes toward feminist movement

\section{WAS WOLLEN DIE WOHL NOCH? DIE ENTWICKLUNG EINER NEUEN MESSSKALA FÜR ZEITGENÖSSISCHE FORMEN DES SEXISMUS}

\author{
Bruno Šimac und Ksenija Klasnić
}

\begin{abstract}
Zusammenfassung
Vorurteile den Frauen gegenüber in Form von Sexismus waren traditionell durch Befürwortung von strengen geschlechtsbedingten Rollen charakterisiert, aber infolge von kulturellen und politischen Änderungen in den letzten Jahrhzehnten wurde die offene Diskriminierung den Frauen gegenüber sozial unannehmbar und der Sexismus nimmt neue, moderne Formen an, die oft unbemerkt, geheim und versteckt bleiben. Das Ziel dieser Arbeit ist, eine neue Skala des modernen Sexismus zu konstruieren und evaluieren, die einige bisher konzeptuell getrennte Formen des modernen Sexismus vereint, sowie einige Inhalte, die bisher nicht in bestehende Skalen der modernen Formen des Sexismus eingeschlossen waren. In Anlehnung an drei Typen von konzeptuell-operationalen Ausarbeitungen des modernen Sexismus - der moderne Sexismus von Swim und Mitarbeiterinnen (1995), Neosexismus von Tougas und Mitarbeiterinnen (1995), sowie ambivalenter Sexismus von Glick und Fiske (1996), wurden konzeptuell und operational zeitgenössische sexistische Stellungnahmen in vier inhaltlichen Grunddomänen ausgearbeitet: 1. Negieren des Bestehens einer weiteren Frauendiskriminierung; 2. Antagonismus den Forderungen von Frauen gegenüber; 3. Erbitterung wegen Sondervorteilen, die Frauen zustehen, nur weil sie Frauen sind 4. Übel nehmen, weil Frauen auf Sexismus und sexuelle Belästigung ,überempfindlich“ reagieren. Die Forschung wurde mit einer Umfrage an einem geeigneten Muster von 402 Studentinnen und Studenten verschiedener Fakultäten der Universität in Zagreb durchgeführt. Die Schlussvariante der Zeitgenössische Sexismus Skala (ZSS) bilden
\end{abstract}


27 Partikel und die Skala stellt ein eindimensinales Messkonstrukt dar. Aufgrund der durchgeführten Analysen kommen die Autoren zum Schluss, dass die ZSS ein Instrument von hoher Zuverlässigkeit ist, dass sie zufriedenstellende inhaltliche, kriterienbezogene und konstruktive Gültigkeit aufweist und sie schlagen weitere Richtlinien für deren Anwendung in weiteren Umfragen vor.

Schlüsselwörter: Diskrimierung von Frauen, geschlechtsbedingte Ungleichberechtigung, Zeitgenössische Sexismus Skala (ZSS), zeitgenössischer Sexismus, traditioneller Sexismus, Stellungnahmen zur feministischen Bewegung 